TITLE:

\title{
Effect of Serpentinite Dehydration in Subducting Slabs on Isotopic Diversity in Recycled Oceanic Crust and Its Role in Isotopic Heterogeneity of the Mantle
}

\section{$\operatorname{AUTHOR}(\mathrm{S}):$}

Shimoda, G.; Kogiso, T.

\section{CITATION:}

Shimoda, G. ... [et al]. Effect of Serpentinite Dehydration in Subducting Slabs on Isotopic Diversity in Recycled Oceanic Crust and Its Role in Isotopic Heterogeneity of the Mantle. Geochemistry, Geophysics, Geosystems 2019, 20(11): 5449-5472

\section{ISSUE DATE:}

2019-11

URL:

http://hdl.handle.net/2433/267490

\section{RIGHT:}

(C) 2019. American Geophysical Union. All Rights Reserved.; The full-text file will be made open to the public on 29 May 2020 in accordance with publisher's 'Terms and Conditions for Self-Archiving'. 


\section{Geochemistry, Geophysics, Geosystems}

\author{
RESEARCH ARTICLE \\ 10.1029/2019GC008336 \\ Key Points: \\ - Dehydration of subducted oceanic \\ crust cannot fully explain isotopic \\ heterogeneity in the mantle \\ - Element partitioning between \\ oceanic crust and fluids derived \\ from slab serpentinite is a major \\ source of mantle isotopic variation \\ - High- $\mu$ mantle is the product of \\ subducted slabs that have been \\ subjected to a highly restricted \\ pressure and temperature path
}

Supporting Information:

- Supporting Information S1

- Table S1

- Figure S1

- Figure S2

- Figure S3

- Figure S4

Correspondence to:

G. Shimoda,

h-shimoda@aist.go.jp

Citation:

Shimoda, G., \& Kogiso, T. (2019). Effect of serpentinite dehydration in

subducting slabs on isotopic diversity in recycled oceanic crust and its role in isotopic heterogeneity of the mantle. Geochemistry, Geophysics, Geosystems, 20, 5449-5472. https://doi.org/10.1029/ 2019GC008336

Received 19 MAR 2019

Accepted 26 SEP 2019

Accepted article online 15 OCT 2019

Published online 29 NOV 2019

\section{Effect of Serpentinite Dehydration in Subducting Slabs on Isotopic Diversity in Recycled Oceanic Crust and Its Role in Isotopic Heterogeneity of the Mantle}

\author{
G. Shimoda ${ }^{1}$ iD and T. Kogiso ${ }^{2}$ iD \\ ${ }^{1}$ Geological Survey of Japan, National Institute of Advanced Industrial Science and Technology, Tsukuba, Japan, \\ ${ }^{2}$ Graduate School of Human and Environmental Studies, Kyoto University, Kyoto, Japan
}

\begin{abstract}
We conducted geochemical modeling of the isotopic evolution of subducted oceanic crust that takes into account the chemical variation produced at mid-ocean ridges and in subduction zones, and examined the suitability of our model for generating the high- $\mu$ (HIMU), focal zone (FOZO), and prevalent mantle (PREMA) mantle components. Chemical variation produced at mid-ocean ridges was represented by the chemical compositions of two groups of mid-ocean ridge basalts (depleted and enriched). Chemical variation produced in subduction zones was investigated with pressure-temperature paths of slabs of different ages (governing the physicochemical conditions of element exchanges), as determined using representative subduction zones involving young (hot), intermediate, and old (cold) slabs. The results suggest that dehydration of oceanic crust cannot alone produce isotopic variation beyond the bounds of PREMA compositions. Producing the wider range of isotopic diversity from PREMA to FOZO requires various degrees of element partitioning between subducted oceanic crust and fluids (aqueous or supercritical) released by dehydration of slab serpentinite. The extremely radiogenic $\mathrm{Pb}$ isotopic signature of HIMU can only be produced by extensive reaction between subducted oceanic crust and fluids derived from slab serpentinite along the specific geothermal gradient resulting from the relatively slow descent of moderately old slabs. The rarity of such tectonic conditions explains the scarcity of HIMU.
\end{abstract}

Plain Language Summary The Earth's mantle has a mixture of different chemical compositions resulting from variations in the subduction of oceanic lithospheric plates (an expression of mantle convection) throughout Earth's history. The mantle sources of the magmas forming today's oceanic plates and islands have been classified into major groups, or components, in the mantle based on evidence from various isotopes, but how these components are formed and maintained has long been debated. It has been inferred that dehydration reactions of oceanic crust (the uppermost layer of oceanic plates) during subduction may be responsible, but dehydration reactions in the crust cannot alone produce the observed mantle components because high-pressure experiments show that the temperatures at which dehydration occurs are too low to sufficiently change the chemistry of plates. We explored the causes of mantle components by using forward modeling. Our model evaluated the effect of serpentinite dehydration in the lithospheric mantle (the lower layer of oceanic plates), which has been poorly modeled in previous studies, and it provided evidence that accounts for the components, including the rare HIMU group, by differences in the temperatures and pressures at which elements are exchanged between subducted oceanic crust and fluids from serpentinite dehydration.

\section{Introduction}

Subduction of crustal material has produced chemical heterogeneity in the mantle since plate tectonics began. This heterogeneity, in turn, is expressed as variations in the isotopic composition of mantle-derived basaltic rocks, such as ocean island basalt (OIB) and mid-ocean ridge basalt (MORB). Therefore, the isotopic variation of recycled crustal materials should be closely linked to the isotopic diversity of global MORB and OIB suites, but this topic has long been a matter of debate (e.g., Allègre \& Turcotte, 1986; Chase, 1981; Elliott et al., 1999; Hart et al., 1992; Hofmann, 1997; Hofmann \& White, 1982; Jackson et al., 2018; Stracke, 2012; Sun \& McDonough, 1989; Weaver, 1991; White, 2015). For a better understanding of how the Earth's interior has chemically evolved since its formation, it is important to have a quantitative understanding of the links between the chemistry of subducted crustal materials and the isotopic diversity of OIB and MORB sources.
(C)2019. American Geophysical Union. All Rights Reserved. 

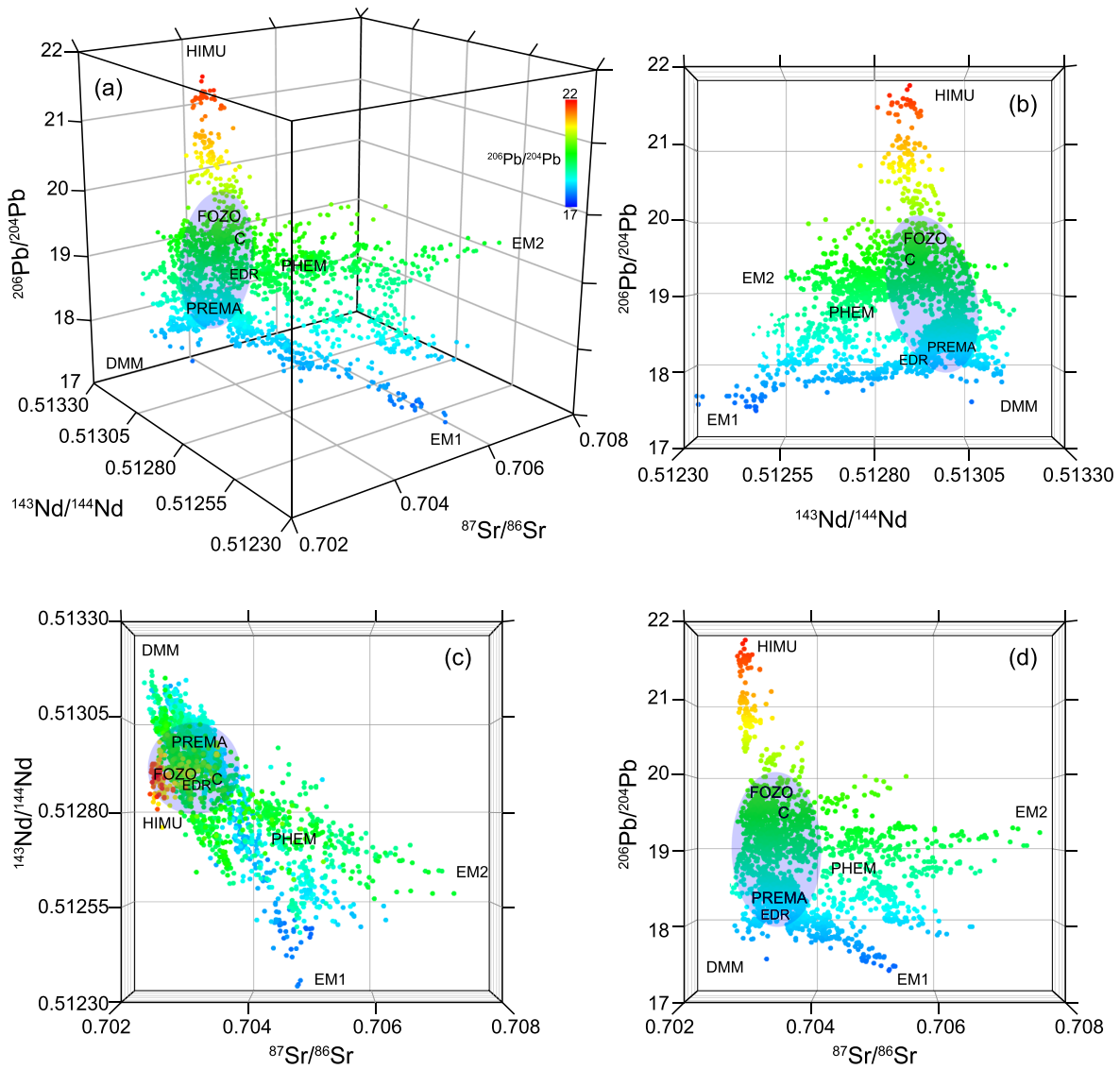

Figure 1. Relationships of ${ }^{87} \mathrm{Sr} /{ }^{86} \mathrm{Sr},{ }^{143} \mathrm{Nd} /{ }^{144} \mathrm{Nd}$, and ${ }^{206} \mathrm{~Pb} /{ }^{204} \mathrm{~Pb}$ in OIBs, with symbol colors indicating values of the ${ }^{206} \mathrm{~Pb} /{ }^{204} \mathrm{~Pb}$ ratio. OIB compositions and representative mantle components are (a) plotted in three dimensions, (b) projected onto the ${ }^{206} \mathrm{~Pb} /{ }^{204} \mathrm{~Pb}$ versus ${ }^{143} \mathrm{Nd} /{ }^{144} \mathrm{Nd}$ field, (c) projected onto the ${ }^{143} \mathrm{Nd} /{ }^{144} \mathrm{Nd}$ versus ${ }^{87} \mathrm{Sr} /{ }^{86} \mathrm{Sr}$ field, and (d) projected onto the ${ }^{206} \mathrm{~Pb} /{ }^{204} \mathrm{~Pb}$ versus ${ }^{143} \mathrm{Nd} /{ }^{144} \mathrm{Nd}$ field. Isotopic compositions of mantle components are indicated by labels (see text for definitions), and the purple fields indicate the isotopic range to which isotopic arrays in OIB converge.

The isotopic diversity of OIB and MORB sources is commonly represented by just four end-member components with extreme isotopic signatures (Hofmann, 1997; White, 1985; Zindler \& Hart, 1986): depleted MORB mantle (DMM), high- $\mu$ (where $\mu={ }^{238} \mathrm{U} /{ }^{204} \mathrm{~Pb}$; HIMU), enriched mantle 1 (EM1), and enriched mantle 2 (EM2; Figure 1). Many studies have proposed that DMM is the residue of upper mantle melting that produced continental crust (e.g., DePaolo \& Wasserburg, 1976a, 1976b; Gast, 1968; Hauri \& Hart, 1993; O'Nions et al., 1977; Richard et al., 1976), that HIMU is derived from recycled oceanic crust (e.g., Castillo, 2015; Chase, 1981; Chauvel et al., 1992; Elliott et al., 1999; Kimura et al., 2016; Kogiso et al., 1997), and that EM1 and EM2 are derived from recycled pelagic and terrigenous sediments, respectively (e.g., Chauvel et al., 1992; Weaver, 1991; White, 1985), or recycled upper and lower continental crustal materials, respectively, via tectonic erosion or delamination (e.g., McKenzie \& O'Nions, 1983; Shimoda, 2009; Willbold \& Stracke, 2006, 2010).

Among these end-member components, HIMU has been considered to be the only one that is mainly affected by recycled oceanic crust (e.g., Chauvel et al., 1992; Kimura et al., 2016; Kogiso et al., 1997). The controversial issue in the production of HIMU is how it resulted in low $\mathrm{Rb} / \mathrm{Sr}$ coexisting with high $\mathrm{U} / \mathrm{Pb}$ and $\mathrm{Th} / \mathrm{Pb}$, because high $\mathrm{U} / \mathrm{Pb}$ and $\mathrm{Th} / \mathrm{Pb}$ imply an enrichment by a melt component in the source materials, which would inevitably produce high $\mathrm{Rb} / \mathrm{Sr}$ ratios (e.g., Stracke et al., 2005). To resolve this issue, many studies have proposed models in which hydrothermal alteration or dehydration of the oceanic crust play a key role (e.g., Chauvel et al., 1992; Hanyu et al., 2011; Hauri \& Hart, 1993; Hofmann \& White, 1982; Kogiso et al., 1997; Weaver, 1991). These studies appear to successfully explain the origin of the HIMU source. However, the rarity of HIMU basalts is difficult to reconcile with the ubiquity of the subduction process (Stracke, 2012; Stracke et al., 2005). 
In contrast to the extreme isotopic compositions of the end-member components, some authors have proposed more common components with intermediate isotopic compositions; discussed here are prevalent mantle (PREMA), focal zone (FOZO), common component (C), and primitive helium mantle (PHEM; Figure 1). The existence of PREMA was proposed to account for the OIB compositions near the enriched (higher ${ }^{87} \mathrm{Sr} /{ }^{86} \mathrm{Sr}$ ) end of the MORB array (Zindler \& Hart, 1986). Hart et al. (1992) postulated the FOZO component, which differs in ${ }^{206} \mathrm{~Pb} /{ }^{204} \mathrm{~Pb}$ composition from PREMA, as occupying the focal area of the fan-shaped distribution of many OIB arrays and away from the MORB field (Figure 1). Hanan and Graham (1996) proposed the C component, similar in composition to FOZO, as the composition to which MORB arrays converge and which produces relatively high ${ }^{3} \mathrm{He} /{ }^{4} \mathrm{He}$ ratios in OIB. Similarly, Farley et al. (1992) advocated the PHEM component that is characterized by high ${ }^{3} \mathrm{He} /{ }^{4} \mathrm{He}$ ratios, FOZO-like $\mathrm{Pb}$ isotopic compositions, and Sr-Nd isotopic ratios near that of the bulk Earth. Stracke et al. (2005) subsequently modified the definition of FOZO to a range of ${ }^{206} \mathrm{~Pb} /{ }^{204} \mathrm{~Pb}$ compositions that includes but extends beyond the high ${ }^{206} \mathrm{~Pb} /{ }^{204} \mathrm{~Pb}$ end of the MORB array. More recent studies have proposed the existence of a deep reservoir of intermediate isotopic composition, formed early in Earth's history, called the early depleted reservoir (EDR), situated near PREMA (Boyet \& Carlson, 2005, 2006; Jackson et al., 2010; Kimura et al., 2017). Although recent studies using the short-lived ${ }^{146} \mathrm{Sm}-{ }^{142} \mathrm{Nd}$ radiometric system have obviated the need for EDR (Bouvier \& Boyet, 2016; Burkhardt et al., 2016), others using geochemical models or the short-lived ${ }^{182} \mathrm{Hf}-{ }^{182} \mathrm{~W}$ radiometric system have suggested that such a reservoir is preserved in the mantle (Kimura et al., 2017; Rizo et al., 2016). Today, there is no consensus about the reason that the OIB isotopic compositions converge into a limited range (purple fields in Figure 1).

Numerical modeling of the isotopic evolution of heterogeneous mantle has demonstrated that continuous subduction of oceanic crust at various periods in geologic time can explain the present-day isotopic distribution of OIB (Christensen \& Hofmann, 1994; Kellogg et al., 2007). However, this isotopic distribution has not yet been quantitatively reconciled with the composition of recycled oceanic crust. Stracke et al. (2005) showed that recycling of present-day MORB can produce in the future an isotopic array that has negative correlations on Sr-Nd and Pb-Nd isotope diagrams (Figures 9 and 10 of Stracke et al. (2005)), which they proposed as an analogue of the present-day isotopic distribution extending from MORB to FOZO. If the recycling of oceanic crust produced FOZO, then the question arises as to what process is responsible for the geochemical difference between FOZO and HIMU, given that HIMU too is thought to originate by recycling of oceanic crust (e.g., Chauvel et al., 1992, 1997; Kimura et al., 2016; Kogiso et al., 1997; Salters \& White, 1998; Stracke et al., 2005). Although the isotopic differences between FOZO and HIMU have been explained as the possible consequence of differences in recycling age (Kimura et al., 2016), very low Rb/Sr ratios coupled with high $\mathrm{U} / \mathrm{Pb}$ ratios of the HIMU source definitely require a chemical difference between HIMU and FOZO, with or without age differences (Stracke, 2012; Stracke et al., 2005). Indeed, several previous studies have shown that the isotopic array of the mantle could not arise from recycling age alone (Iwamori et al., 2010; Iwamori \& Albarède, 2008; Rudge, 2006; Rudge et al., 2005).

Although the origin of the end components is still controversial, there is general agreement that the subduction process is essential in generating the isotopic heterogeneity of the mantle. Dehydration reactions in oceanic crust during the subduction process have been extensively studied, but the effect of serpentinite dehydration of the slab mantle on oceanic crust chemistry is poorly understood. Recent work has produced geophysical and petrological evidence that the upper oceanic lithosphere is pervasively serpentinized, although the depth range of serpentinization is highly controversial, with estimates ranging from a few kilometers to 40 km (Andreani et al., 2007; Billen \& Gurnis, 2005; Cai et al., 2018; Contreras-Reyes, Grevemeyer, Flueh, \& Reichert, 2008, Contreras-Reyes, Grevemeyer, Flueh, Scherwath, et al., 2008; Escartin et al., 1997; Faccenda et al., 2009; Garth \& Rietbrock, 2014, 2017; Nedimović et al., 2009; Ranero et al., 2003, 2005). As serpentinite can contain as much as $13 \%$ water, serpentinized mantle may be a major source of water in a subducted slab (e.g., Hacker, 2008; Peacock, 2001; van Keken et al., 2011). In addition, given that serpentinite is the product of reactions between peridotite and seawater, its chemical composition should inherit the chemical signature of seawater (e.g., high concentrations of Rb and U; Deschamps et al., 2013; Niu, 2004). It follows that fluid derived from serpentinite in subducting slabs can induce major chemical fractionation as it passes through and reacts with the overlying oceanic crust. Therefore, the effects of serpentinite dehydration, along with dehydration of the oceanic crust, should be evaluated for a quantitative understanding of mantle heterogeneity caused by recycled oceanic crust. 
In this study, we addressed these issues by forward modeling of the isotopic evolution of subducted oceanic crust, focusing on the compositional variation of recycled oceanic crust. Because oceanic crust changes in composition during subduction, as a result of various degrees of dehydration of the oceanic crust itself and reaction with fluids created by serpentinite dehydration of the underlying slab mantle, subducted oceanic crust should give rise to a corresponding range of isotopic compositions in the mantle. We calculated the isotopic evolution of subducted oceanic crust over geologic time and investigated whether the resulting isotopic variation is quantitatively consistent with the isotopic diversity of OIB including HIMU, especially the convergence of OIB to FOZO.

\section{Chemical and Isotopic Modeling of Recycled Oceanic Crust}

We modeled the isotopic evolution of recycled oceanic crust, paying particular attention to the effects of different degrees of dehydration in subducting slabs upon isotopically important parent-daughter element pairs ( $\mathrm{Rb}-\mathrm{Sr}, \mathrm{Sm}-\mathrm{Nd}$, Lu-Hf, and $\mathrm{Pb}-\mathrm{Th}-\mathrm{U}$ ). Note that the definition of dehydration processes in this study is rather restricted, assuming that elements in oceanic crust are only mobilized by aqueous or supercritical fluids in an equilibrium state and excluding the effects of other dehydration-related processes, such as dehydration melting and flux melting. To explore the effect of initial chemical variations produced at mid-ocean ridges on isotopic variations of recycled oceanic crust, we adopted the normal MORB (N-MORB) composition of Sun and McDonough (1989), which is a geochemically depleted composition, and the average MORB composition of Gale et al. (2013), which is a geochemically relatively enriched composition, to represent the range of oceanic crust before it undergoes alteration and subduction (Figure 2a). Although the composition of MORB can only represent the upper part of the oceanic crust (up to 40\%), considering that the major-element compositions of oceanic gabbro and MORB are similar (Pertermann \& Hirschmann, 2003) and that the trace-element patterns of N-MORB and average MORB are also fairly smooth (Figure 2a), elemental ratios used in this study should not be very different from those of bulk oceanic crust. Hence, although our assumption is admittedly imperfect, our modeling used MORB compositions to represent the composition of oceanic crust.

The effects of seawater alteration on chemical composition were estimated on the basis of previous studies of Site 801, Site 1149, and Site 504 in the western and eastern Pacific Ocean; Site 417/418 in the Atlantic Ocean; and Site 735 on the Southwest Indian Ridge (Alt et al., 1996; Alt \& Teagle, 2003; Bach et al., 2001, 2003; Contreras-Reyes, Grevemeyer, Flueh, \& Reichert, 2008; Hart \& Staudigel, 1989; Jarrard, 2003; Kelley et al., 2003; Plank et al., 2000; Staudigel, 2003; Staudigel et al., 1995, 1996; van Avendonk et al., 2011). Our estimation included redeterminations of the bulk chemical composition of oceanic crust before and after alteration and the age effect of seawater alteration on the composition of oceanic crust (Supporting information S1). Because these studies showed that the main chemical effect of alteration is to increase concentrations of alkalis (e.g., $\mathrm{Rb}$ ) and $\mathrm{U}$, we used a composition for altered oceanic crust that differed from unaltered crust only in its $\mathrm{Rb}$ and $\mathrm{U}$ concentrations (Table 1).

\subsection{Dehydration of Oceanic Crust}

The water content of oceanic crust varies from nearly dry (<1\%) to over 6\% (e.g., Bach et al., 2001, 2003; Plank et al., 2000; Robinson et al., 1997; Staudigel et al., 1995, 1996) and possibly to approximately $10 \%$ (Ridley et al., 1994), owing to differences in the extent of alteration (Plank et al., 2000; Stakes \& Franklin, 1994). Because water contents of the oceanic crust reach up to 6\% (Hacker, 2008; Hacker et al., 2003; Iwamori, 1998, 2007; Poli \& Schmidt, 1995; Schmidt \& Poli, 1998), we modeled crustal dehydration using $6 \%$ as the maximum water content of hydrated oceanic crust and $0 \%$ (dry MORB) as the minimum. The extent to which elements are removed from oceanic crust during subduction depends on the pressure and temperature $(P-T)$ conditions of dehydration reactions (e.g., Green \& Adam, 2003; Kessel, Schmidt, et al., 2005). To evaluate the effect of temperature, we modeled three representative subduction zones: a hot (young) one based on the South Chile subduction zone (10.3 Ma), an intermediate one based on the Western Aleutian subduction zone (56.1 Ma), and a cold (old) one based on the South Marianas subduction zone (151.6 Ma; Syracuse \& Abers, 2006; Syracuse et al., 2010, and references therein).

For each of the three model subduction zones, we estimated the effect of dehydration using the $P-T$ paths of descending slabs reported by Syracuse et al. (2010) and the stability fields of hydrous minerals reported by Hacker et al. (2003). According to these sources, major dehydration reactions occur at similar temperatures but at different depths due to the strong temperature dependence of dehydration reactions, as shown in 

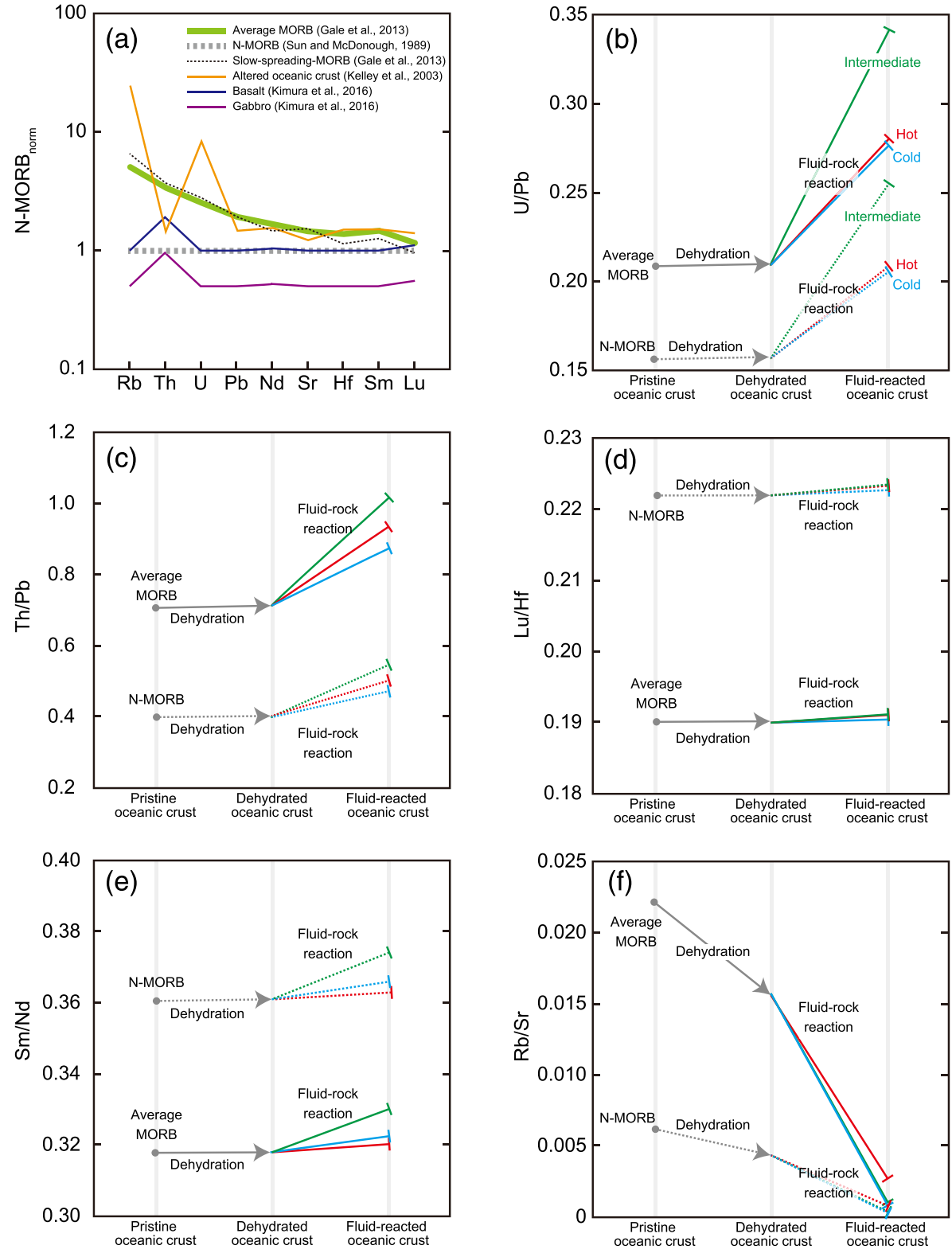

Figure 2. N-MORB normalized trace-element compositions and elemental ratios used in this and previous studies. (a) NMORB normalized trace element compositions of average MORB (thick green line) and MORB produced at slow-spreading ridges (dotted black line), altered oceanic crust composition (orange line), lower basaltic layer (LBAS in Kimura et al., 2016; blue line), and gabbroic layer (GAB in Kimura et al., 2016; purple line). Also shown are changes in (b) U/Pb, (c) Th/Pb, (d) Lu/Hf, (e) Sm/Nd, and (f) Rb/Sr in average MORB (Gale et al., 2013) and average N-MORB (Sun \& McDonough, 1989) with dehydration and fluid-rock reactions in hot (red), cold (blue), and intermediate (green) subduction zones.

Figure $3 \mathrm{a}\left(470-480{ }^{\circ} \mathrm{C}\right.$ in the hot subduction zone at $2.1-2.3 \mathrm{GPa}, 440-460{ }^{\circ} \mathrm{C}$ in the intermediate subduction zone at 2.6-3.7 GPa, and $425-460{ }^{\circ} \mathrm{C}$ in the cold subduction zone at 2.7-4.3 GPa). Although small amounts of water still remain in the slab after these major dehydration reactions, the chemical effect of the dehydration of the remaining water should be limited. Therefore, we focused on testing the effect of major dehydration reactions. Because partition coefficients have not been determined at temperatures as low as these, we used the partition coefficients experimentally determined at $650{ }^{\circ} \mathrm{C}$ and $3 \mathrm{GPa}$ (Green \& Adam, 2003). We used the same partition coefficient values listed in Table 2 for all three subduction zones because pressure has a much smaller effect than temperature on element solubilities (Manning, 2004). Note that because element solubilities in aqueous fluids increase with temperature (Manning, 2004; Nakamura \& Kushiro, 1974; Plank et al., 2009), and given the lack of experimental constraints, our use of these partition 


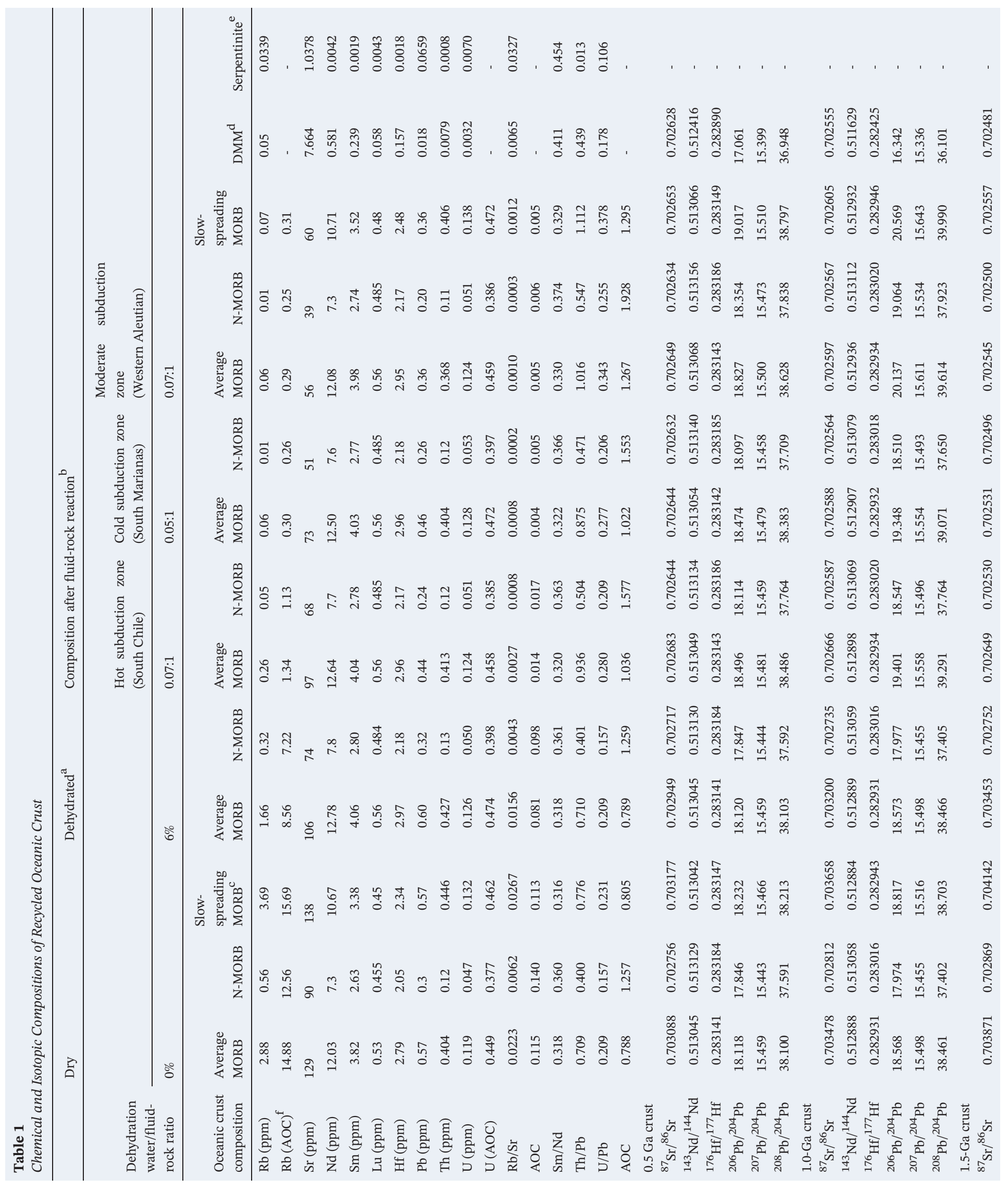




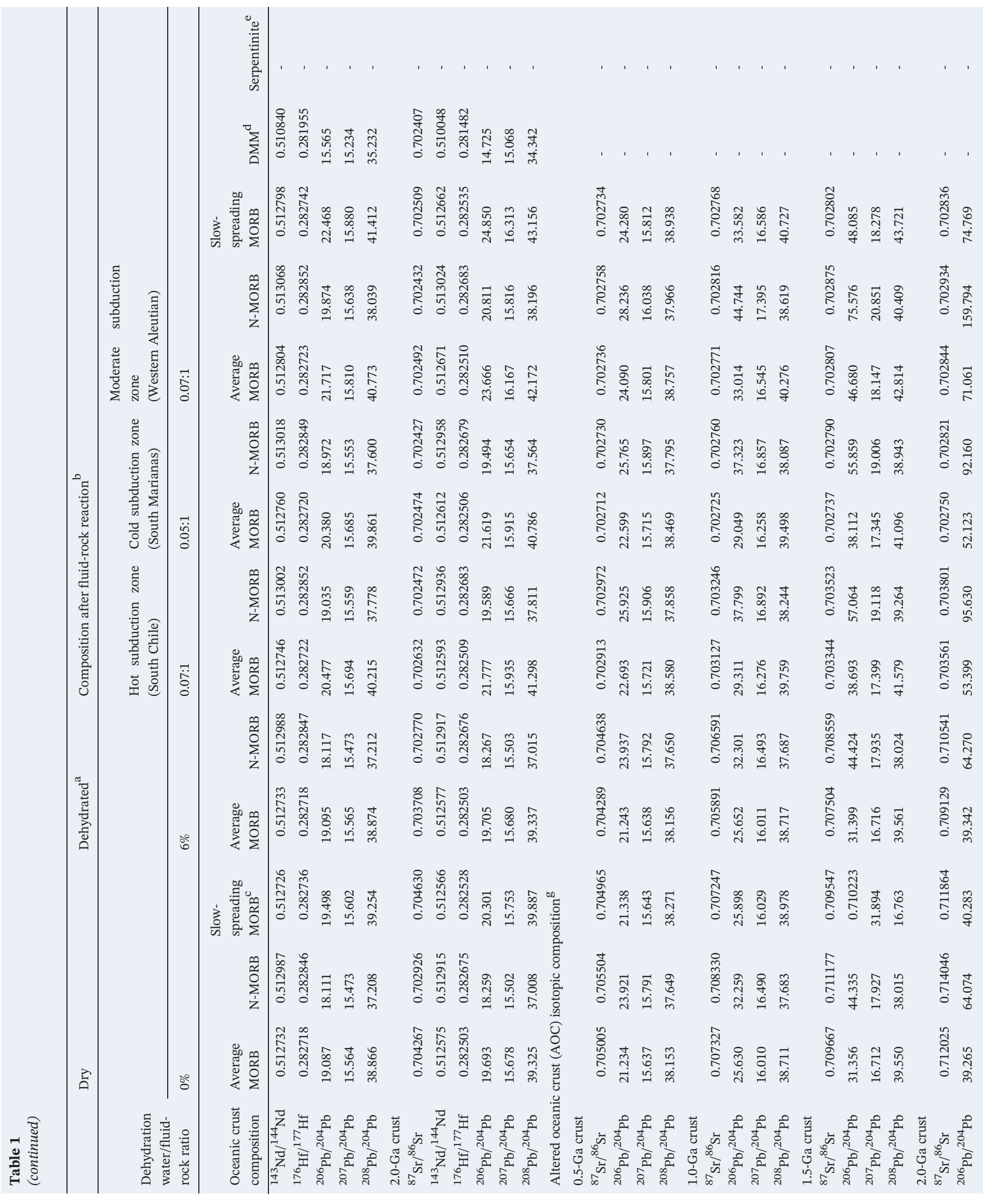




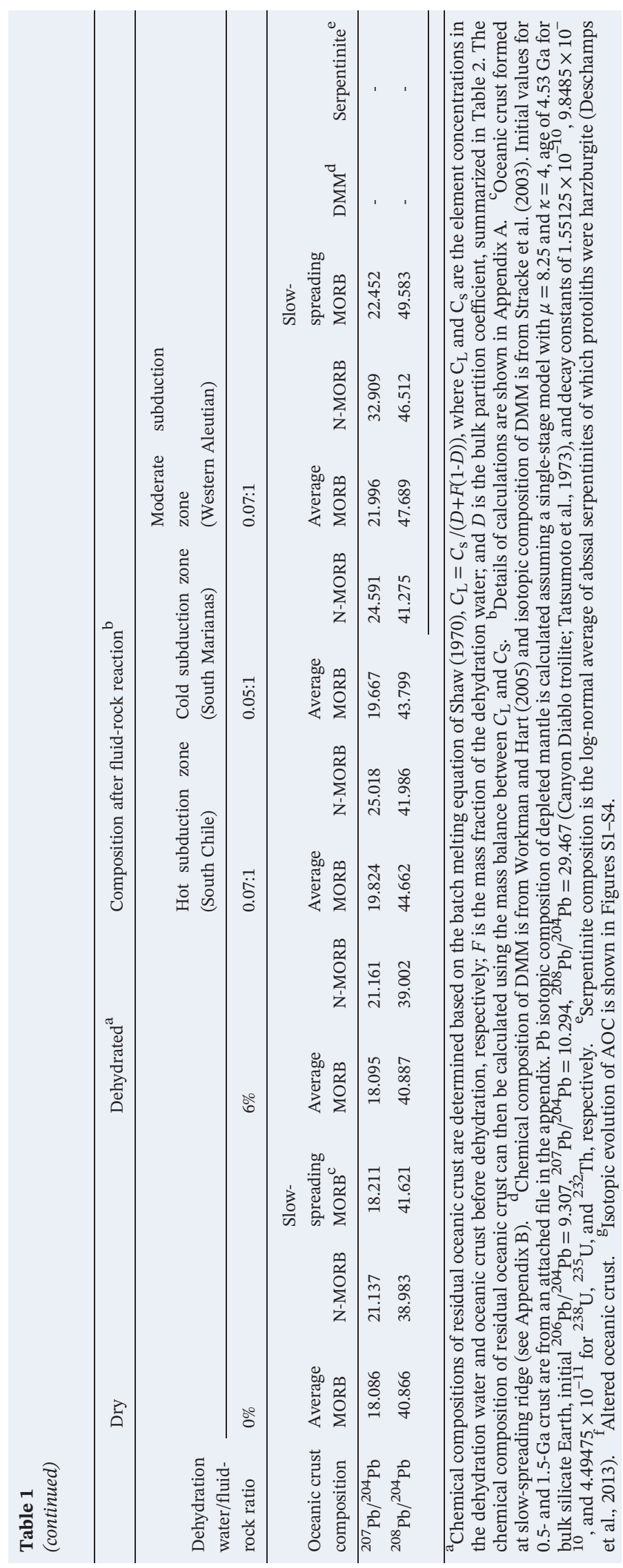




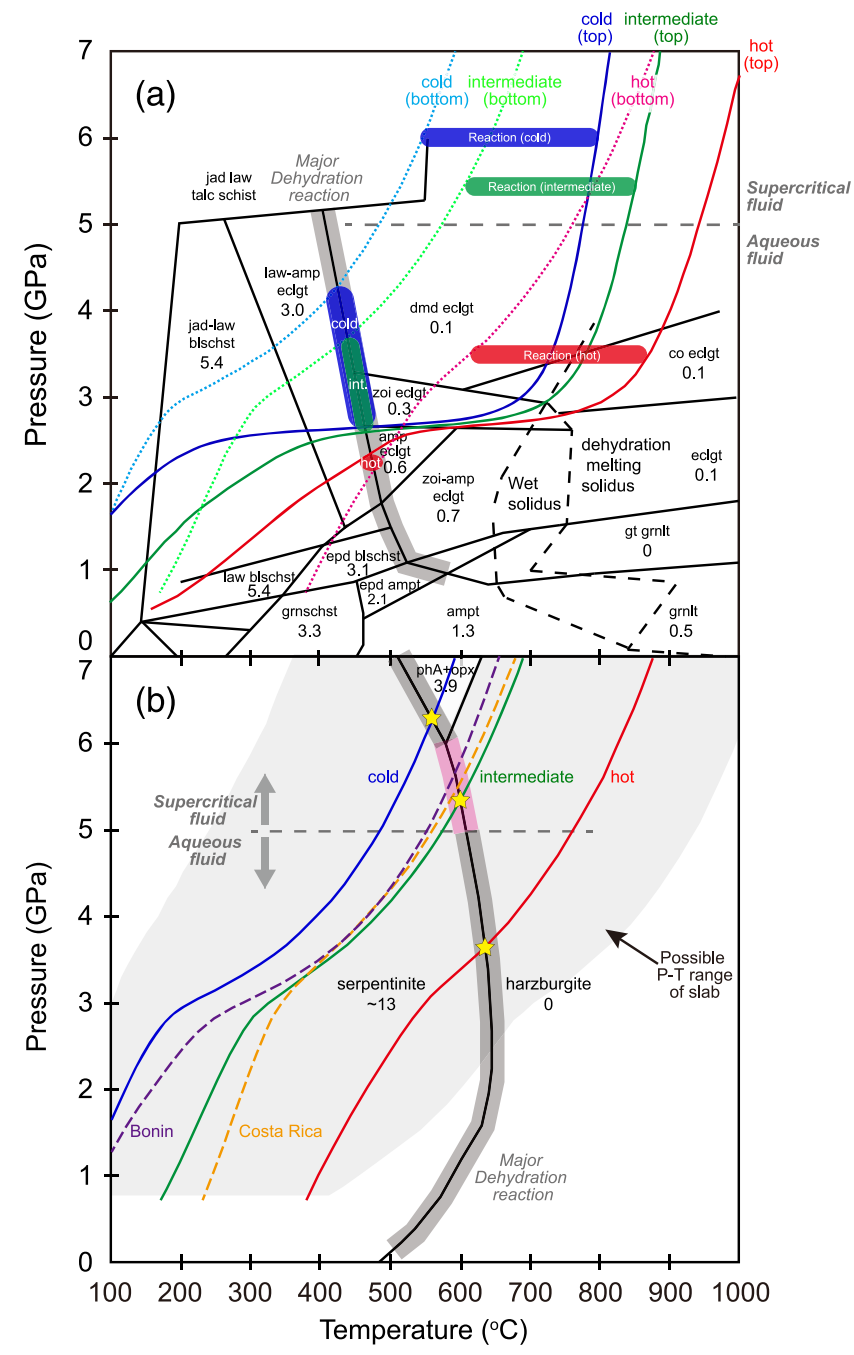

Figure 3. $P-T$ paths of subducting slabs in cold (blue lines), intermediate (green lines), and hot (red lines) subduction zones. $P$ - $T$ conditions were determined with the D80 model of Syracuse et al. (2010). Stability fields of hydrous phases are from Hacker et al. (2003); numbers in each field are the percent water in the oceanic crust. (a) $P$ - $T$ paths of the top of the oceanic crust (solid colored lines) and the base of the crust (dotted colored lines). Abbreviations: amp, amphibole; ampt, amphibolite; blschst, blueschist; co, coesite; dmd, diamond; eclgt, eclogite; epd, epidote; grnlt, granulite; grnschst, greenschist; gt, garnet; jad, jadeite; law, lawsonite; zoi, zoisite. The thick gray curve represents the main dehydration reaction line of basaltic systems (Hacker et al., 2003); superimposed on it are colored segments corresponding to cold (blue), intermediate (int.; green), and hot (red) subduction zones. $P$ - $T$ conditions of fluid-rock reactions are also shown by colored horizontal bars, extending from the top to the bottom of the crust, for the three subduction zone categories. The gray dashed line at $5 \mathrm{GPa}$ is the inferred boundary between supercritical and aqueous fluids. (b) $P$ - $T$ path of the top of the subducted slab mantle in cold, intermediate, and hot subduction zones; dashed lines represent the Bonin (purple) and Costa Rica (orange) subduction zones. Abbreviations: opx, orthopyroxene; phA, phase A. The thick dark gray curve represents the $P-T$ conditions of the major dehydration reaction; the stars mark the conditions of serpentinite dehydration in the three subduction zone classes, and the pink segment represents the conditions of serpentinite dehydration suitable for the production of HIMU, bounded by the field of aqueous fluid and the stability field of hydrous phase A. The light gray shading represents the range of possible $P$ - $T$ conditions at the top of the slab mantle, determined from $P$ - $T$ paths of the Tonga (cold) and North Cascadia (hot) subduction zones.

coefficients limited us to estimating the maximum effects of dehydration on oceanic crust chemistry. Chemical compositions of subducted oceanic crust were estimated for two different conditions, that is, no dehydration (dry oceanic crust) and 6\% dehydration (water saturated oceanic crust) using the chemical compositions of N-MORB and average MORB, plus their alteration products (Table 1 and Figure 2). Effects of dehydration were estimated using the batch melting equation of Shaw (1970). 
Table 2

Partition Coefficients Used in the Dehydration and Water-Rock Reaction Calculations

\begin{tabular}{|c|c|c|c|c|c|c|c|c|c|}
\hline & Dehydration $^{\mathrm{a}}$ & Fluid-rock & tion (hot sub & tion zone) ${ }^{\mathrm{b}}$ & Fluid-rock 1 & ion (cold/int & ediate subdu & n zone $)^{\mathrm{c}}$ & Serpentinite $^{\mathrm{d}}$ \\
\hline & $650^{\circ} \mathrm{C}$ & $700^{\circ} \mathrm{C}$ & $800^{\circ} \mathrm{C}$ & $900^{\circ} \mathrm{C}$ & $800^{\circ} \mathrm{C}$ & $900^{\circ} \mathrm{C}$ & $1000^{\circ} \mathrm{C}$ & $1200^{\circ} \mathrm{C}$ & \\
\hline $\mathrm{Rb}$ & 0.0751 & 0.011 & 0.019 & 0.013 & 0.00419 & 0.00323 & 0.015 & 0.0102 & 0.0102 \\
\hline $\mathrm{Sr}$ & 0.22 & 2.9 & 0.526 & 0.0474 & 0.035 & 0.0313 & 0.012 & 0.0081 & 0.0081 \\
\hline $\mathrm{Nd}$ & 37.0 & 18 & 6.85 & 0.661 & 0.525 & 0.325 & 0.0511 & 0.039 & 0.039 \\
\hline $\mathrm{Sm}$ & 65.0 & 39 & 15 & 2.70 & 1.5 & 1.1 & 0.27 & 0.14 & 0.14 \\
\hline $\mathrm{Lu}$ & 386 & 238 & 195 & 107 & 42 & 60 & 13 & 4.39 & 4.39 \\
\hline $\mathrm{Hf}$ & 126 & 47 & 16 & 1.9 & 6.41 & 1.78 & 0.19 & 0.0793 & 0.0793 \\
\hline $\mathrm{Pb}$ & 6.62 & 0.31 & 0.0526 & 0.0318 & 0.0402 & 0.0392 & 0.021 & 0.00922 & 0.00922 \\
\hline Th & 8.47 & 8.37 & 2.3 & 0.16 & 0.17 & 0.0408 & 0.016 & 0.00410 & 0.00410 \\
\hline U & 8.44 & 6.98 & 0.977 & 0.17 & 0.479 & 0.24 & 0.0400 & 0.00599 & 0.00599 \\
\hline Fraction & tion factor ${ }^{\mathrm{e}}$ & & & & & & & & \\
\hline $\mathrm{Rb} / \mathrm{Sr}$ & - & 34.84 & 6.37 & 1.39 & 1.39 & 1.36 & 0.97 & 0.97 & - \\
\hline $\mathrm{Sm} / \mathrm{Nd}$ & - & 0.47 & 0.45 & 0.27 & 0.38 & 0.34 & 0.37 & 0.52 & - \\
\hline $\mathrm{Lu} / \mathrm{Hf}$ & - & 0.20 & 0.08 & 0.02 & 0.15 & 0.03 & 0.02 & 0.03 & - \\
\hline $\mathrm{Th} / \mathrm{Pb}$ & - & 0.05 & 0.05 & 0.46 & 0.46 & 0.99 & 1.06 & 1.06 & - \\
\hline $\mathrm{U} / \mathrm{Pb}$ & - & 0.05 & 0.12 & 0.44 & 0.21 & 0.37 & 0.84 & 1.04 & - \\
\hline
\end{tabular}

${ }^{a}$ Bulk partition coefficients during dehydration of oceanic crust were calculated based on reported data determined at 3 GPa and phase modes determined by Schmidt et al. (2004): $47.3 \%$ garnet, $38.9 \%$ clinopyroxene, $12.4 \%$ quartz/coesite, and $1.4 \%$ rutile, after recalculation to $100 \%$ total. Partition coefficients are from Green and Adam (2003) for garnet and clinopyroxene, from Ayers (1998) for rutile, and zero is assumed for quartz/coesite. Partition coefficients of Hf and Lu into rutile were assumed to be identical to those of $\mathrm{Zr}$ and $\mathrm{Tm}$ from Ayers (1998). Bulk partition coefficients of Nd into garnet and rutile were estimated based on the equation $\mathrm{Kd}_{\mathrm{Nd}}=\left(\mathrm{Kd}_{\mathrm{Sm}}+\mathrm{Kd}_{\mathrm{Ce}}\right) / 2$. ${ }^{\mathrm{b}}$ Partition coefficients are from Kessel, Schmidt, et al. (2005) determined at $4 \mathrm{GPa}$ for aqueous fluid. ${ }^{\mathrm{c}}$ Partition coefficients are from Kessel, Schmidt, et al. (2005) determined at $6 \mathrm{GPa}$ for supercritical fluid. ${ }^{\mathrm{d}}$ Bulk partition coefficients of serpentinite were estimated based on the assumption that serpentinite becomes harzburgite after dehydration, consisting of $70 \%$ olivine and $30 \%$ orthopyroxene. Partition coefficients of olivine and pyroxene are from Adam et al. (2014), Ayers (1998), and Brenan et al. (1995). The partition coefficient of Pb into orthopyroxene was assumed to be identical to that for olivine. The partition coefficient of $\mathrm{Hf}$ into olivine is assumed to be identical to that of $\mathrm{Zr}$. ${ }^{\mathrm{e}}$ Fractionation factors were determined with the equation $F R=\left(D_{\mathrm{d}}+F\left(1-D_{\mathrm{d}}\right)\right) /\left(D_{\mathrm{p}}+F\left(1-D_{\mathrm{p}}\right)\right)$, where $F R$ is the fractionation factor, $F$ is the weight fraction of fluid, and $D_{\mathrm{p}}$ and $D_{\mathrm{d}}$ are partition coefficients of parent and daughter elements. We assumed a fluid fraction of $7 \%$ for the maximum fluid-rock ratio. Elemental fractionation is stronger when the fractionation factor is large and both parent and daughter elements are incompatible.

\subsection{Fluid-Rock Reaction Caused by Serpentinite Dehydration}

Serpentinite is recognized as a major water reservoir in subducted slabs (e.g., Scambelluri et al., 2004; Spandler \& Pirard, 2013; Yogodzinski et al., 2017), and dehydration of serpentinite causes chemical fractionation of the overlying oceanic crust in subducting slabs through fluid-rock reactions. Accordingly, the degree and spatial extent of serpentinization in the slab mantle are indispensable information for quantitative modeling of chemical fractionation in subducted oceanic crust, although they are poorly constrained and subject to a variety of tectonic conditions such as the angle between the current trench and the ancient spreading ridge, plate age, and other factors (e.g., Faccenda, 2014; Fujie et al., 2018; Nedimović et al., 2009). The most extensively hydrated plate may be the northwestern part of the Pacific plate beneath northern Japan, where a layer $40 \mathrm{~km}$ thick that is $17-31 \%$ serpentinized has been documented (Garth \& Rietbrock, 2014). However, because more than 10\% serpentinization would decrease the density of the slab mantle to the extent that it would interfere with subduction (Schmidt \& Poli, 1998), we assumed that maximum hydration of the slab mantle is limited to a layer that is $10 \%$ serpentinized and $40 \mathrm{~km}$ thick, which corresponds to a water content of $1.3 \%$ in that part of the slab mantle. Note that the maximum depth of serpentinization is debated.

The amount of water released by serpentinite dehydration depends on the $P$ - $T$ path of the slab. In hot and intermediate subduction zones, serpentinite can be completely dehydrated and release up to $13 \%$ of its mass in water (Figure 3b; Bose \& Ganguly, 1995; Hacker, 2008; Iwamori, 2000, 2004; Peacock \& Wang, 1999; Ulmer \& Trommsdorff, 1995). In cold subduction zones, where the $P-T$ path of the serpentinite layer crosses the stability field of phase A (dense hydrous magnesium silicate, $\mathrm{Mg}_{7} \mathrm{Si}_{2} \mathrm{O}_{8}(\mathrm{OH})_{6}$ ), serpentinite can be partially dehydrated and release no more than 9\% water (Iwamori, 2000, 2004; Komabayashi, Hirose, et al., 2005; Peacock, 2001). The remaining water, hosted in phase A, can be carried into the mantle transition zone and possibly into the lower mantle (Komabayashi \& Omori, 2006; Komabayashi, Hirose, et al., 2005, 
Komabayashi, Omori, et al., 2005; Nishi et al., 2014; Ohtani et al., 2018; Shieh et al., 1998). Hence, we assumed that the amount of dehydration water from serpentinite in the cold subduction zone is no greater than $9 \%$. It follows that the maximum water-rock ratios are 0.07:1 in hot and intermediate subduction zones and 0.05:1 in cold subduction zones for an assumed average thickness of oceanic crust of $7 \mathrm{~km}$ (Mutter \& Mutter, 1993; White et al., 1992). Compositions of serpentinite-derived fluid were determined from the average serpentinite composition of Deschamps et al. (2013), the batch melting equation of Shaw (1970), and partition coefficients listed in Table 2. Although the chemical composition of serpentinite is affected by elements in seawater, the concentrations of these elements are much lower in serpentinite than in MORB (Table 1), such that the effect of adding serpentinite-derived fluid to oceanic crust is negligible.

Serpentinite dehydration was inferred to occur at $3.5 \mathrm{GPa}$ and $620^{\circ} \mathrm{C}$ in the hot subduction zone, $5.3 \mathrm{GPa}$ and $600{ }^{\circ} \mathrm{C}$ in the intermediate subduction zone, and $6.0 \mathrm{GPa}$ and $550{ }^{\circ} \mathrm{C}$ in the cold subduction zone (Figure $3 \mathrm{~b}$ and Table 2). Because the serpentinite layer is in contact with oceanic crust, we assumed for simplicity that serpentinite dehydration and fluid-rock reactions occurred at the same pressure. As for the temperature conditions, fluid-rock reactions were inferred to occur over temperature ranges of $620-870{ }^{\circ} \mathrm{C}$ in the hot subduction zone, $600-850{ }^{\circ} \mathrm{C}$ in the intermediate subduction zone, and $550-800{ }^{\circ} \mathrm{C}$ in the cold subduction zone (horizontal bars in Figure 3a), the low and high temperatures corresponding to the cold base and the hot upper surface of the slab crust. Because solubilities change with temperature, fluid-rock reactions occur at high temperatures after dehydration of oceanic crust and further increase the chemical fractionation as the slab heats up. Effects of these temperature ranges on partition coefficients were estimated based on their log-linear correlation on a plot of partition coefficient versus reciprocal temperature (Appendix A).

It has been reported that the second critical endpoint in basaltic systems lies between 5 and 6 GPa (Kessel, Ulmer, et al., 2005; Mibe et al., 2011). Accordingly, pressure is important for fluid-rock reactions because they involve aqueous fluid in the hot subduction zone and supercritical fluid in the intermediate and cold subduction zones (Figure 3a). Chemical compositions of oceanic crust after fluid-rock reactions, estimated with the batch melting equation (Shaw, 1970) and the partition coefficients shown in Table 2 and Figure A1, are summarized in Table 1 and Figure 2. The major differences between reactions with aqueous and supercritical fluids arise from two considerations: solubilities of elements are much greater in supercritical fluid than in aqueous fluid, and solubilities of elements in aqueous fluid have a stronger temperature dependence than in supercritical fluid, such that solubilities are very small at low temperatures (Kessel, Schmidt, et al., 2005; Figure A1). Thus, large chemical differences can develop in residual oceanic crusts through fluid-rock reactions, as supercritical fluid can cause greater chemical fractionation than aqueous fluid during reactions that occur at relatively low temperatures (e.g., Hacker, 2008; Peacock, 2001; Syracuse et al., 2010; van Keken et al., 2011). Note that the presence of phase A decreases the amount of released fluid and thus tends to reduce the degree of chemical fractionation in cold subduction zones (Figure 2). The temperature gradient in the subducted slab means that serpentinite dehydration may occur over a specific pressure range; however, for simplicity we assumed dehydration to occur at certain $P$ - $T$ conditions.

It may be worthwhile to verify the consistency between our assumptions on serpentinite subduction in this study and the reported water budget of the Earth, because serpentinite subduction may be a major water flux to the deep mantle (Parai \& Mukhopadhyay, 2012; van Keken et al., 2011). Although we assumed subduction of a thick serpentinite layer, dehydration reactions at hot and intermediate subduction zones release essentially all of the water in the slab mantle, suggesting a trivial amount of water transport to the deep mantle. In contrast, serpentinite subduction at cold subduction zones can transfer large amounts of water to the deep mantle in phase A after dehydration (i.e., $\sim 0.4 \%$ water in a layer $40 \mathrm{~km}$ thick). This value can be reconciled with a reported water flux equivalent to a 500-m thickness of pure serpentinite (Parai \& Mukhopadhyay, 2012) if cold subduction zones constitute less than $40 \%$ of all subduction zones. Consequently, there appears to be no contradiction between our assumptions on serpentinite subduction and estimated water flux to the deep mantle.

\section{Results and Discussion}

\subsection{Effect of Dehydration of Oceanic Crust}

We calculated the isotopic evolution of selected elements in subducted oceanic crust with recycling ages from 2.0 to $0.5 \mathrm{Ga}$ under the assumption that the initial isotopic composition of oceanic crust was that of 
DMM at the time of subduction, as estimated by Stracke et al. (2003) (Table 1). The results are shown in Figure 4. The effect of seawater alteration on ${ }^{87} \mathrm{Sr} /{ }^{86} \mathrm{Sr}$ ratios in oceanic crust is significant but difficult to constrain because it depends on the ${ }^{87} \mathrm{Sr} /{ }^{86} \mathrm{Sr}$ ratio of ancient seawater and the extent of isotopic exchange during alteration. Thus, in Figure $4 \mathrm{c}$ we show only the reported shift in ${ }^{87} \mathrm{Sr} /{ }^{86} \mathrm{Sr}$ of bulk altered oceanic crust determined at Site 417/418 (Hart et al., 1999; Staudigel, 2003; Staudigel et al., 1981, 1995). As this shift was determined for the upper $500 \mathrm{~m}$ of old oceanic crust $(118 \mathrm{Ma})$, it may represent a realistic maximum value if we take into account the isotopic evolution of seawater from approximately 0.704 at 2 Ga to approximately 0709 at present (Shields et al., 2003; Shields \& Veizer, 2002). The effect of seawater alteration on the chemical composition of oceanic crust is discussed further in section 3.3.

As shown in Figure 4, the calculated isotopic compositions of dehydrated oceanic crust (open diamonds) are nearly identical to those of unmodified (dry) oceanic crust (open squares), except in the case of Sr, which differs from the other elements considered in that only $\mathrm{Rb}$ is mobile in fluids at our assigned $P$ - $T$ conditions. It follows that the effect of dehydration on the chemical composition of residual oceanic crust is negligible, except for Rb/Sr (Figure 2f; Green \& Adam, 2003; Hermann et al., 2006). As mentioned in the previous section, our calculations are an estimate of the maximum effect of dehydration. Consequently, it is reasonable to infer that dehydration alone could not produce large isotopic variations in oceanic crust, although dehydration has been inferred to be essential for the production of HIMU (e.g., Kogiso et al., 1997). Instead, differences in the recycling age and chemical composition of oceanic crust may account for these isotopic variations, particularly those in $\mathrm{Pb}$ isotopes.

It is widely accepted that most of the water in oceanic crust is released beneath the forearc area $(\sim 80-\mathrm{km}$ depth) at relatively low temperatures around $500{ }^{\circ} \mathrm{C}$ (Hacker, 2008; Hermann et al., 2006; Kelemen et al., 2003; Okamoto \& Maruyama, 2004; Omori et al., 2004; Schmidt \& Poli, 1998; Tatsumi, 1989). The solubility of elements in water is low at low P-T conditions (Green \& Adam, 2003; Hermann et al., 2006). It follows that dehydration cannot explain the $\mathrm{Pb}$ isotopic compositions of HIMU, or even FOZO. To reproduce the $\mathrm{Pb}$ isotopic composition of HIMU and FOZO requires strong fractionation of $\mathrm{U} / \mathrm{Pb}$ to occur in residual oceanic crust; an example would be changing $\mathrm{U} / \mathrm{Pb}$ ratios from less than 0.2 , typical of dry oceanic crust, to more than 0.3 . Such a degree of $\mathrm{U} / \mathrm{Pb}$ fractionation is possible at temperatures above $800{ }^{\circ} \mathrm{C}$, at which $\mathrm{Pb}$ behaves as a moderately or highly incompatible element (see fractionation factors in Table 2) and can be removed from oceanic crust more effectively than U and Th (Kessel, Schmidt, et al., 2005). However, dehydration is unlikely at such high temperatures because most dehydration reactions within oceanic crust are complete at approximately $500{ }^{\circ} \mathrm{C}$ (e.g., Hacker et al., 2003). Accordingly, an additional process other than dehydration is required to produce the $\mathrm{Pb}$ isotopic composition of HIMU and possibly FOZO.

\subsection{Effect of Serpentinite Dehydration}

Dehydration of serpentinite in subducting slabs is important for the fluid-rock reactions that can be expected to cause chemical modification of oceanic crust (e.g., Spandler \& Pirard, 2013). Indeed, reactions between average MORB of various ages and serpentinite-derived fluids can produce the $\mathrm{Pb}$ isotopic variations ranging from PREMA to HIMU (large solid symbols in Figures $4 \mathrm{a}, 4 \mathrm{~b}, 4 \mathrm{e}$, and $4 \mathrm{f}$ ) because they take place at higher $P-T$ conditions than dehydration reactions (Table 2 and Figure 3). In contrast to average MORB, the depleted composition of N-MORB can only produce small isotopic variations distributed near PREMA (small colored symbols in Figure 4a), although the low Th/U ratio of N-MORB results in unrealistically high ${ }^{206} \mathrm{~Pb} /{ }^{204} \mathrm{~Pb}$ and low ${ }^{208} \mathrm{~Pb} /{ }^{204} \mathrm{~Pb}$ ratios in recycled oceanic crust older than $1.5 \mathrm{Ga}$ (small colored symbols in Figure 4b). Therefore, a combination of three factors-oceanic crust chemistry, degree of fluid-rock reaction, and recycling age - could produce the range of $\mathrm{Pb}$ isotopic variation between PREMA and HIMU. Similarly, the ${ }^{87} \mathrm{Sr} /{ }^{86} \mathrm{Sr}$ versus ${ }^{143} \mathrm{Nd} /{ }^{144} \mathrm{Nd}$ and ${ }^{143} \mathrm{Nd} /{ }^{144} \mathrm{Nd}$ versus ${ }^{176} \mathrm{Hf} /{ }^{177} \mathrm{Hf}$ diagrams show that the calculated isotopic compositions of young $(\leq 1.0 \mathrm{Ga})$ recycled oceanic crust are limited to the area near PREMA and FOZO (Figures 4c and 4d).

Note that most of the calculated Pb isotopic compositions lie between PREMA and FOZO. The HIMU isotopic composition $\left({ }^{206} \mathrm{~Pb} /{ }^{204} \mathrm{~Pb}>21.5\right)$ is only produced within narrow constraints: recycling of moderately old oceanic crust $(1.5 \mathrm{Ga})$ with the composition of average MORB that passes through the intermediate $P-T$ path (orange solid stars in Figures $4 \mathrm{a}$ and $4 \mathrm{~b}$ ). Although earlier recycling of oceanic crust (2.0 Ga) can produce extreme HIMU Pb isotopic compositions (red solid symbols in Figures $4 \mathrm{a}$ and $4 \mathrm{~b}$ ), such an old recycling age necessarily produces high ${ }^{206} \mathrm{~Pb} /{ }^{204} \mathrm{~Pb}$ and ${ }^{207} \mathrm{~Pb} /{ }^{204} \mathrm{~Pb}$, which contradicts a key distinguishing character 

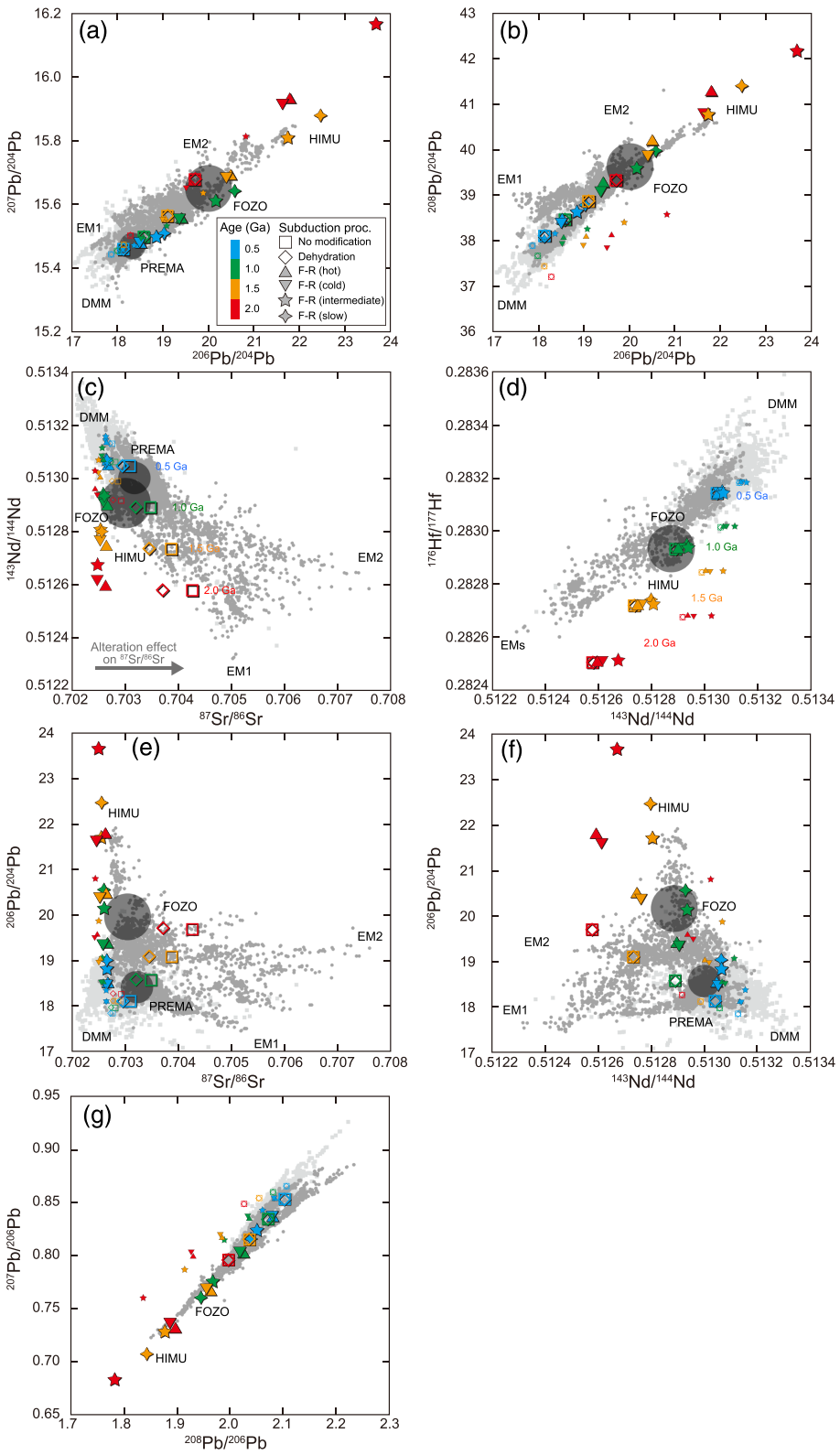

Figure 4. Estimated isotopic compositions of recycled oceanic crust with N-MORB chemical composition (small symbols) and average MORB composition (large symbols). Initial isotopic ratios of MORB are identical to those of DMM (Stracke et al., 2003). (a) ${ }^{207} \mathrm{~Pb} /{ }^{204} \mathrm{~Pb}$ versus ${ }^{206} \mathrm{~Pb} /{ }^{204} \mathrm{~Pb}$, (b) ${ }^{208} \mathrm{~Pb} /{ }^{204} \mathrm{~Pb}$ versus ${ }^{206} \mathrm{~Pb} /{ }^{204} \mathrm{~Pb}$, (c) ${ }^{143} \mathrm{Nd} /{ }^{144} \mathrm{Nd}$ versus ${ }^{87} \mathrm{Sr} /{ }^{86} \mathrm{Sr}$, (d) ${ }^{176} \mathrm{Hf} /{ }^{177} \mathrm{Hf}$ versus ${ }^{143} \mathrm{Nd} /{ }^{144} \mathrm{Nd}$, (e) ${ }^{206} \mathrm{~Pb} /{ }^{204} \mathrm{~Pb}$ versus ${ }^{87} \mathrm{Sr} /{ }^{86} \mathrm{Sr}$, (f) ${ }^{206} \mathrm{~Pb} /{ }^{204} \mathrm{~Pb}$ versus ${ }^{143} \mathrm{Nd} /{ }^{144} \mathrm{Nd}$, and $(\mathrm{g}){ }^{207} \mathrm{~Pb} /$ ${ }^{206} \mathrm{~Pb}$ versus ${ }^{208} \mathrm{~Pb} /{ }^{206} \mathrm{~Pb}$. Recycled oceanic crust without modification by subduction and dehydrated oceanic crust are shown with open squares and open diamonds, respectively. Colored symbols indicate recycled oceanic crust that experienced fluid-rock reaction (F-R) at hot, intermediate, and cold subduction zones (triangles, stars, and inverted triangles, respectively) and oceanic crust formed at slow-spreading ridges, recycled through the intermediate $P$ - $T$ path (four-pointed stars; 2.0-Ga recycling case not shown). Symbol colors indicate the recycling age: blue, 0.5 Ga; green, $1.0 \mathrm{Ga}$; orange, 1.5 $\mathrm{Ga}$; and red, $2.0 \mathrm{Ga}$. Gray dots and light gray squares are OIB and MORB compositions, respectively, compiled by Salters et al. (2011) and Stracke (2012). Fluid-rock reaction of oceanic crust with lesser degrees of serpentinization produces isotopic compositions plotting between the open diamonds and the colored symbols. Isotopic compositions of mantle components are indicated by labels or dark gray fields; ${ }^{208} \mathrm{~Pb} /{ }^{204} \mathrm{~Pb}$ and ${ }^{176} \mathrm{Hf} /{ }^{177} \mathrm{Hf}$ have not been determined for PREMA and thus PREMA is not shown in (b), (d), and (g). The ${ }^{87} \mathrm{Sr} /{ }^{86} \mathrm{Sr}$ shift from 0.7029 to $0.7046(+0.0017)$ at Site 417/ 418 caused by seawater alteration (Hart et al., 1999; Staudigel, 2003; Staudigel et al., 1981, 1995) is signified by the gray arrow in (c). As this isotopic shift was estimated in the upper part of old oceanic crust (118 Ma) and as ${ }^{87} \mathrm{Sr} /{ }^{86} \mathrm{Sr}$ of seawater has evolved with time from approximately 0.704 at 2 Ga to approximately 0709 at present (Shields et al., 2003; Shields \& Veizer, 2002), it may represent the maximum isotopic shift resulting from seawater alteration. 
of HIMU, namely, high ${ }^{206} \mathrm{~Pb} /{ }^{204} \mathrm{~Pb}$ but low ${ }^{207} \mathrm{~Pb} /{ }^{204} \mathrm{~Pb}$ (Figure 4a). Additionally, the extremely low Hf and $\mathrm{Nd}$ isotopic compositions of oceanic crust recycled at $2.0 \mathrm{Ga}$ (red solid symbols in Figures $4 \mathrm{~d}$ and $4 \mathrm{f}$ ) suggest that such recycling ages are not suitable for generation of HIMU (Halldórsson et al., 2016; Iwamori et al., 2010; Iwamori \& Albarède, 2008; Rudge, 2006; Rudge et al., 2005). Although Kimura et al. (2016) have shown that very early recycling of oceanic crust $(\sim 2.5 \mathrm{Ga})$ can produce HIMU, this result may reflect a combination of $U$ enrichment in the upper altered layer of oceanic crust and Th enrichment in the lower basaltic and gabbroic layers (Figure 2a). Although such an enrichment pattern may be plausible, such an old recycling age would necessarily result in both high ${ }^{206} \mathrm{~Pb} /{ }^{204} \mathrm{~Pb}$ and ${ }^{207} \mathrm{~Pb} /{ }^{204} \mathrm{~Pb}$ ratios, which is not a defining feature of HIMU. Hence, it is reasonable to infer that only subduction zones with recycling ages less than approximately $1.5 \mathrm{Ga}$ and under limited $P-T$ conditions can produce HIMU.

The two main differences that distinguish production of HIMU from production of FOZO or PREMA can be summarized as follows. The first concerns the solubility of elements. Solubilities in aqueous fluid are strongly temperature-dependent and are quite low at the temperatures typical of serpentinite dehydration (approximately $500{ }^{\circ} \mathrm{C}$; Green \& Adam, 2003; Kessel, Schmidt, et al., 2005); thus, production of HIMU by chemical fractionation is unlikely in aqueous fluid. However, solubilities in supercritical fluid are high and less dependent on temperature (Kessel, Schmidt, et al., 2005), such that fractionation could raise $\mathrm{U} / \mathrm{Pb}$ ratios from approximately 0.2 in average MORB to approximately 0.3 after fluid-rock reaction even at the $P$ - $T$ conditions of serpentinite dehydration (Table 1 ). The solubility of $\mathrm{Pb}$, in particular, is much higher in supercritical fluid than in aqueous fluid (Figure A1; see also the fractionation factors in Table 2) and would lead to stronger fractionation in $\mathrm{U} / \mathrm{Pb}$. Thus, reaction with supercritical fluid appears to be favorable for the production of HIMU. Because the pressure threshold for the transition from aqueous to supercritical fluid lies between 5 and 6 GPa (Kessel, Ulmer, et al., 2005; Mibe et al., 2007, 2011), the production of the HIMU source is most favored in parts of subduction zones where serpentinite dehydration can occur at pressures of at least $5 \mathrm{GPa}$ (Figure 3b).

The other important condition for the production of the HIMU source is high fluid-rock ratios during reactions, inducing strong chemical fractionation. For example, fractionation at the maximum fluid-rock ratio (0.07:1) assumed for the intermediate subduction zone can change the $\mathrm{U} / \mathrm{Pb}$ ratio from approximately 0.2 to 0.3 , sufficient to produce HIMU, in oceanic crust with average MORB composition and a 1.5-Ga recycling age. Because the presence of phase A reduces the amount of dehydration fluid and thereby suppresses the chemical effect of fluid-rock reaction (Figure 2), only $P$ - $T$ paths passing through the limited part of the main dehydration curve in Figure $3 b$ below the phase A stability field (the pink segment) can produce HIMU. If this is the case, then the $P-T$ range in which slabs can produce HIMU is limited to a very small portion of the full $P$ - $T$ range of slabs (gray shaded area in Figure 3b; Syracuse et al., 2010).

Our modeling shows that suitable $P$ - $T$ paths of a slab to produce HIMU are limited to intermediate subduction zones, as exemplified by the Western Aleutian subduction zone involving a moderately old plate (56.1 $\mathrm{Ma})$. However, the $P-T$ path of a given slab is also subject to various other factors beside the age of the plate, such as the slab descent rate and sediment thickness (e.g., Syracuse et al., 2010). For example, Figure 3b shows that the slab in the Costa Rica subduction zone, which is young (15.8 Ma) and fast-sinking (63.9 km/Myr), and the slab in the Bonin subduction zone, which is old (145.3 Ma) and slow-sinking $(28.1 \mathrm{~km} / \mathrm{Myr})$, can both intersect the same section of the major dehydration reaction curve as the intermediate (Western Aleutian) slab (56.1 Ma and 42.0-km/Myr descent rate); thus, the $P-T$ conditions at these subduction zones also allow the production of the HIMU source.

\subsection{Effect of Alteration of Oceanic Crust}

It has long been noted that alteration processes of oceanic crust have an essential role in the production of HIMU (e.g., Chauvel et al., 1992). In particular, Castillo (2015) stressed the importance of carbonate added to oceanic crust for the production of HIMU because of its high U concentration. However, as Kelley et al. (2005) reported, alteration fails to reproduce the isotopic composition of HIMU as well as the isotopic variation of OIB, instead resulting in very high ${ }^{206} \mathrm{~Pb} /{ }^{204} \mathrm{~Pb}$ values (approximately 30 at 1.5 Ga-recycling age) and very low ${ }^{208} \mathrm{~Pb} /{ }^{204} \mathrm{~Pb}$ values (approximately 40 at 1.5 -Ga recycling age) that have never been observed in OIB (Table 1 and Figure S1-4b). These extraordinary ratios resulted from strong enrichment of U relative to Th due to precipitation of secondary carbonate from seawater (e.g., Bach et al., 2003; Kelley et al., 2003; Staudigel et al., 1996). As the effect of alteration was estimated based on upper part of oceanic crust 
(Supporting information S1), mixing between upper and lower curst could reduce the effect of alteration if the lower crust remained fresh. However, even in that case, isotopic composition of altered oceanic crust should evolve to different direction from OIB isotopic array in ${ }^{206} \mathrm{~Pb} /{ }^{204} \mathrm{~Pb}$ and ${ }^{208} \mathrm{~Pb} /{ }^{204} \mathrm{~Pb}$ isotopic field. Therefore, if carbonate remains stable along subduction P-T paths (e.g., Connolly, 2005; Dasgupta \& Hirschmann, 2010; Gorman et al., 2006; Hammouda, 2003; Poli et al., 2009), then subducted oceanic crust should have very high ${ }^{206} \mathrm{~Pb} /{ }^{204} \mathrm{~Pb}$ and very low ${ }^{208} \mathrm{~Pb} /{ }^{204} \mathrm{~Pb}$ values that are well outside the range of OIB isotopic compositions (Table 1 and Figure S1-4b). This contradiction could be explained by the change in atmospheric oxygen fugacity at approximately $2 \mathrm{Ga}$ (Elliott et al., 1999). However, crustal recycling of that age does not reproduce either the $\mathrm{Nd}-\mathrm{Pb}$ isotopic composition of OIB (Figure $4 \mathrm{f}$ ) or the combination of high ${ }^{206} \mathrm{~Pb} /{ }^{204} \mathrm{~Pb}$ and low ${ }^{207} \mathrm{~Pb} /{ }^{206} \mathrm{~Pb}$ of HIMU (Figure $4 \mathrm{a}$ ), as mentioned previously. Hence, a process is needed that can decrease the U/Th ratio of subducted oceanic crust, as has previously been shown for the Mariana arc (Kelley et al., 2005). Indeed, much evidence suggests that external fluid derived from serpentinite dehydration in the underlying slab mantle effectively dissolves the carbonate in subducted oceanic crust, almost completely stripping it from the subducted slab (e.g., Ague \& Nicolescu, 2014; Brovarone et al., 2018; Facq et al., 2014, 2016; Frezzotti et al., 2011; Fryer et al., 1999; Kawamoto et al., 2013; Kelemen \& Manning, 2015; Piccoli et al., 2016, 2018; Spandler \& Pirard, 2013). It follows that secondary U hosted in carbonate could be lost from the slab during subduction. Although only a very small amount of carbonate is sufficient to explain the high ${ }^{206} \mathrm{~Pb} /{ }^{204} \mathrm{~Pb}$ value of HIMU (Castillo, 2015), producing high ${ }^{206} \mathrm{~Pb} /{ }^{208} \mathrm{~Pb}$ by carbonate addition appears to be problematic.

\subsection{Why Is HIMU Rare?}

As discussed previously, it can be inferred that four conditions favor the production of HIMU: (1) oceanic crust similar to or more enriched than average MORB composition (Gale et al., 2013), (2) high fluid-rock ratio, (3) limited range of $P-T$ path, and (4) limited range of recycling age (1.0-1.5 Ga). This section presents details of these conditions and addresses the rare occurrence of HIMU.

To produce high fluid-rock ratios, a critical factor is the number density of faults, which allow for fluid infiltration deep into oceanic plates (Fisher et al., 2003). This aspect of crustal structure depends on the spreading rate of ridges; in particular, crust produced at slow-spreading ridges is relatively thin (1-7 km) with many large normal faults on the ridge flank as the result of intermittent magmatism. Thin, highly faulted crust permits deep fluid circulation, which promotes serpentinization of the oceanic mantle (e.g., Carbotte \& Scheirer, 2004; Deschamps et al., 2013; Ildefonse et al., 2007; Mével, 2003). In addition, thin crust tends to have a high ratio of slab mantle to basaltic crust, further contributing to high fluid-rock ratios during subduction. Significantly, crust produced at slow-spreading ridges has a chemical composition more enriched than N-MORB and even average MORB, which enables it to produce enriched isotopic compositions (Table 1, Figure 2a, and Appendix B). Indeed, the average MORB produced at slow spreading rates (10-40 $\mathrm{mm}$ /year) can produce $\mathrm{Pb}$ isotopic compositions typical of the HIMU end component (Table 1; four-pointed orange stars in Figures 4a, 4b, 4e, 4f; and Appendix B). Oceanic crust produced at slow spreading ridges amounts to about $20 \%$ of the annual production of oceanic crust by area (Gale et al., 2013), a proportion that is even smaller by volume, which is consistent with the rarity of HIMU.

It has been proposed that the degree of serpentinization is correlated with plate age because older plates are affected by large tensional stresses, which may produce cracks penetrating as deep as $50 \mathrm{~km}$ in a plate of 100Myr age (Korenaga, 2007, 2017). In addition, the greater depth of the brittle-ductile transition in old oceanic plates favors deeper faulting (Contreras-Reyes, Grevemeyer, Flueh, Scherwath, et al., 2008, 2011; Watts, 2001). The gentle temperature gradient in old oceanic lithosphere increases the depth range of favorable temperatures for serpentinization. Indeed, observations suggest that the degree of plate hydration at the outer rise may be dependent on plate age (Garth \& Rietbrock, 2017). However, the $P$ - $T$ path of old oceanic plates can cross the stability field of phase A, which reduces the amount of dehydration water they release. Similarly, dehydration of thick serpentinite layers should occur within a certain pressure range due to the thermal gradient within slabs, resulting in incomplete dehydration wherever phase A is stable in the deeper part of the serpentinite layer. To completely dehydrate serpentinite in old slabs, warmer tectonic settings, such as the initial stage of subduction, may be required to sufficiently heat the deep parts of old slabs (van Keken et al., 2018). These constraints further limit the tectonic conditions suitable for HIMU production to a narrow range of descent rates. And although the $P-T$ path in some young subduction zones (e.g., 
Costa Rica) may favor HIMU production (Figure 3b), young subduction zones may offer small opportunities for serpentinization of the slab mantle (Faccenda, 2014; Garth \& Rietbrock, 2017; Nakajima et al., 2011; Nedimović et al., 2009; Ranero et al., 2003, 2005; van Keken et al., 2011).

In summary, the four conditions for HIMU production constrain it to oceanic crust with relatively enriched chemical composition that undergoes pervasive hydration during its passage from ridge to trench and then takes a tightly limited $P-T$ path during subduction (Figure $3 \mathrm{~b}$ ). These stringent constraints help explain the scarcity of HIMU OIB; however, this statement is conditioned on the assumptions and simplifications we adopted for our modeling. It is necessary to gain a quantitative understanding of the uncertainties due to the assumptions and simplifications of our model as well as the inherited errors from the results of highpressure experiments and geophysical modeling upon which this study has relied.

\section{Conclusions}

Geochemical modeling elucidates the genetic link between the HIMU, FOZO, and PREMA mantle components and subducted oceanic crust as the consequence of chemical variations produced at mid-ocean ridges and subduction zones. Our results show that radiogenic isotopic ratios for dry or dehydrated oceanic crust with average MORB composition are moderately depleted and are comparable to PREMA after recycling at about 0.5-1.5 Ga. In contrast, extensive reaction between subducting crust and fluids from serpentinite dehydration can produce high ${ }^{206} \mathrm{~Pb} /{ }^{204} \mathrm{~Pb}$ and ${ }^{143} \mathrm{Nd} /{ }^{144} \mathrm{Nd}$ ratios and low ${ }^{87} \mathrm{Sr} /{ }^{86} \mathrm{Sr}$ ratios at both hot and cold subduction zones, and is thus a suitable mechanism for the origin of FOZO. Oceanic crust with depleted chemical composition (N-MORB) can produce PREMA-like isotopic compositions, but its depleted chemical composition is unlikely to produce FOZO-like $\mathrm{Pb}$ isotopic compositions by any processes occurring at subduction zones. Hence, the isotopic array extending from PREMA to FOZO can be explained by recycling of oceanic crust with variable chemical compositions that in turn is chemically modified by different degrees of fluid-rock reaction induced by serpentinite dehydration. HIMU isotopic compositions can be explained as the rare result of a process in which oceanic crust with a composition similar to or more enriched than average MORB, underlain by intensively serpentinized slab mantle, passes through a restricted $P-T$ path upon subduction. Thus, variations in the extent of serpentinization of plates before subduction and diversity in the $P-T$ paths of slabs during subduction may be essential in producing the isotopic variations among PREMA, FOZO, and HIMU. Specifically, the $\mathrm{Pb}, \mathrm{Nd}$, and $\mathrm{Sr}$ isotopic compositions of PREMA, FOZO, and HIMU are all affected by slab recycling.

\section{Appendix A: Estimation of Effect of Thermal Gradient in Slab A.}

Because partition coefficients and the inverse of temperature show a strong linear correlation in a logarithmic plot (Figure A1), the partition coefficient of an element at temperature $T$ can be written as

$$
\begin{gathered}
D=a \mathrm{e}^{b t}, \\
t=1 / T,
\end{gathered}
$$

where $D$ is the bulk partition coefficient, $a$ and $b$ are the constants obtained from the regression line, and $T$ is the temperature. Applying the batch melting equation, the fluid composition can be calculated from

$$
C_{\mathrm{L}}=C_{\mathrm{S}} /(D+F(1-D))
$$

where $C_{\mathrm{L}}$ and $C_{\mathrm{S}}$ are the element concentrations in the fluid and source material, respectively, and $F$ is the mass fraction of water relative to the initial mass. Inserting equation (1) into equation (3) gives

$$
C_{\mathrm{L}}=C_{\mathrm{S}} /\left(a \mathrm{e}^{b t}+F\left(1-a \mathrm{e}^{b t}\right)\right) .
$$

Assuming that $t$ (inverse of temperature) in the slab (oceanic crust) and depth in the slab are linearly correlated, then the relationship between depth and $t$ is 

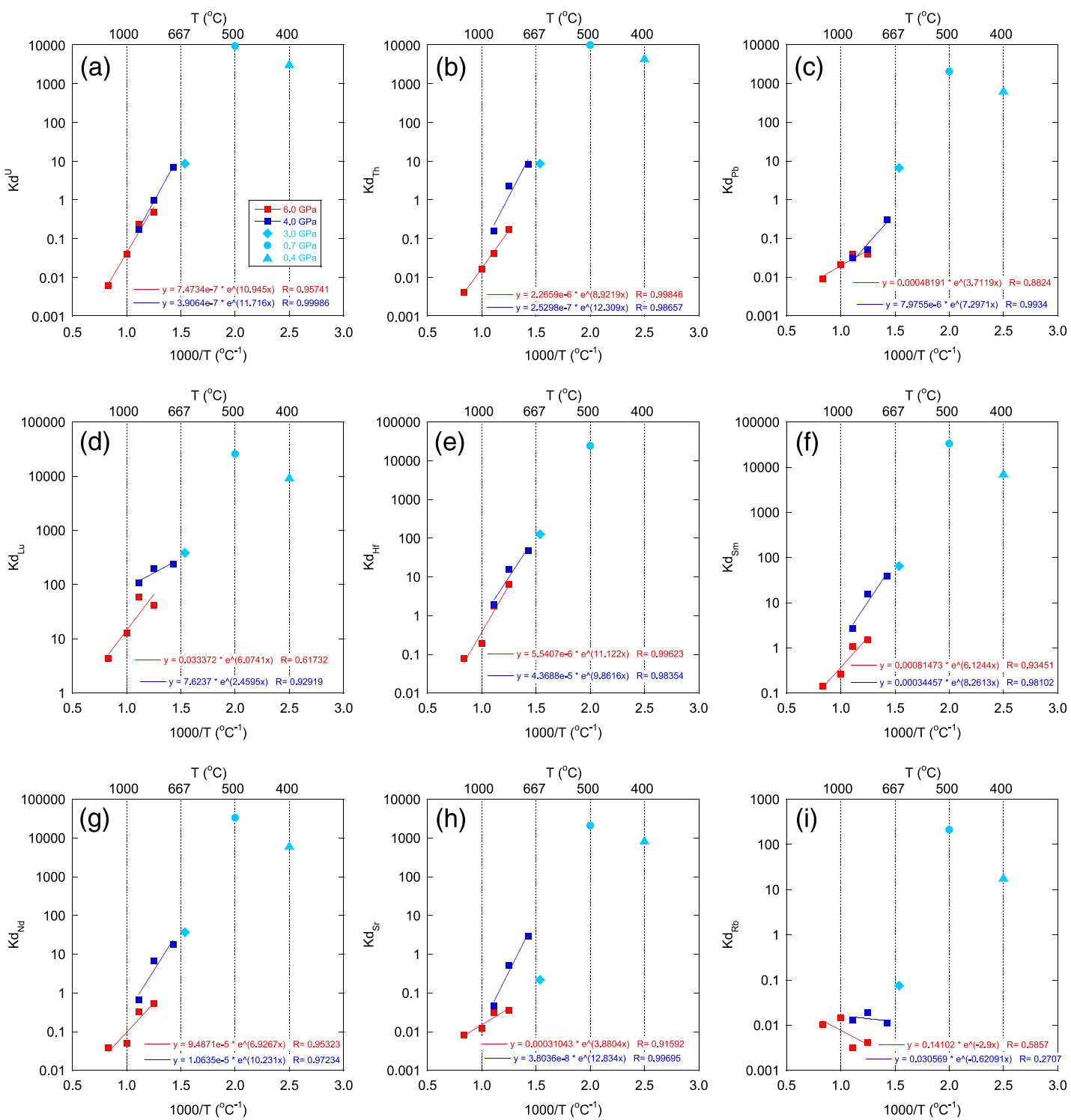

Figure A1. Relationship between partition coefficients (Kd) and inverse of temperature (1/T) at different pressures for (a) U, (b) Th, (c) Pb, (d) Lu, (e) Hf, (f) Sm (g) $\mathrm{Nd}$, (h) Sr, and (i) Rb. Blue square symbols are for $4 \mathrm{GPa}$ (aqueous fluid) and red square symbols are for $6 \mathrm{GPa}$ (supercritical fluid). Partition coefficients are from Kessel, Schmidt, et al. (2005). Regression lines and their equations are also shown. Note that partition coefficients determined for melt at 4 GPa were excluded. Light blue symbols represent partition coefficients for aqueous fluid at low temperatures and pressures: $3 \mathrm{GPa}$ (diamonds; Green \& Adam, 2003 ), $0.7 \mathrm{GPa}$ (circles; Mutter et al., 2014), and $0.4 \mathrm{GPa}$ (triangles; Mutter et al., 2014). These roughly align with the regression lines for aqueous fluid, suggesting that the partition coefficients can be extrapolated to low $P$ - $T$ conditions.

$$
t=k x+w
$$

where $x$ is the depth from the surface of the oceanic crust and $k$ and $w$ are the constants for the linear correlation between slab depth and slab temperature, respectively. This correlation is an approximation to simplify calculations that can be considered realistic at relatively high pressure (Figure A2). Hence, the assumption of this linear correlation is applicable to estimating chemical effects of fluid-rock reaction on residual oceanic crust. Inserting equation (5) into equation (4) gives

$$
C_{\mathrm{L}}=C_{\mathrm{S}} /\left(a \mathrm{e}^{b(k x+w)}+F\left(1-a \mathrm{e}^{b(k x+w)}\right)\right) .
$$

Integrating $C_{\mathrm{L}}$ from the top to the bottom of the oceanic crust and then dividing by the thickness of the oceanic crust yields the chemical composition of fluid: 

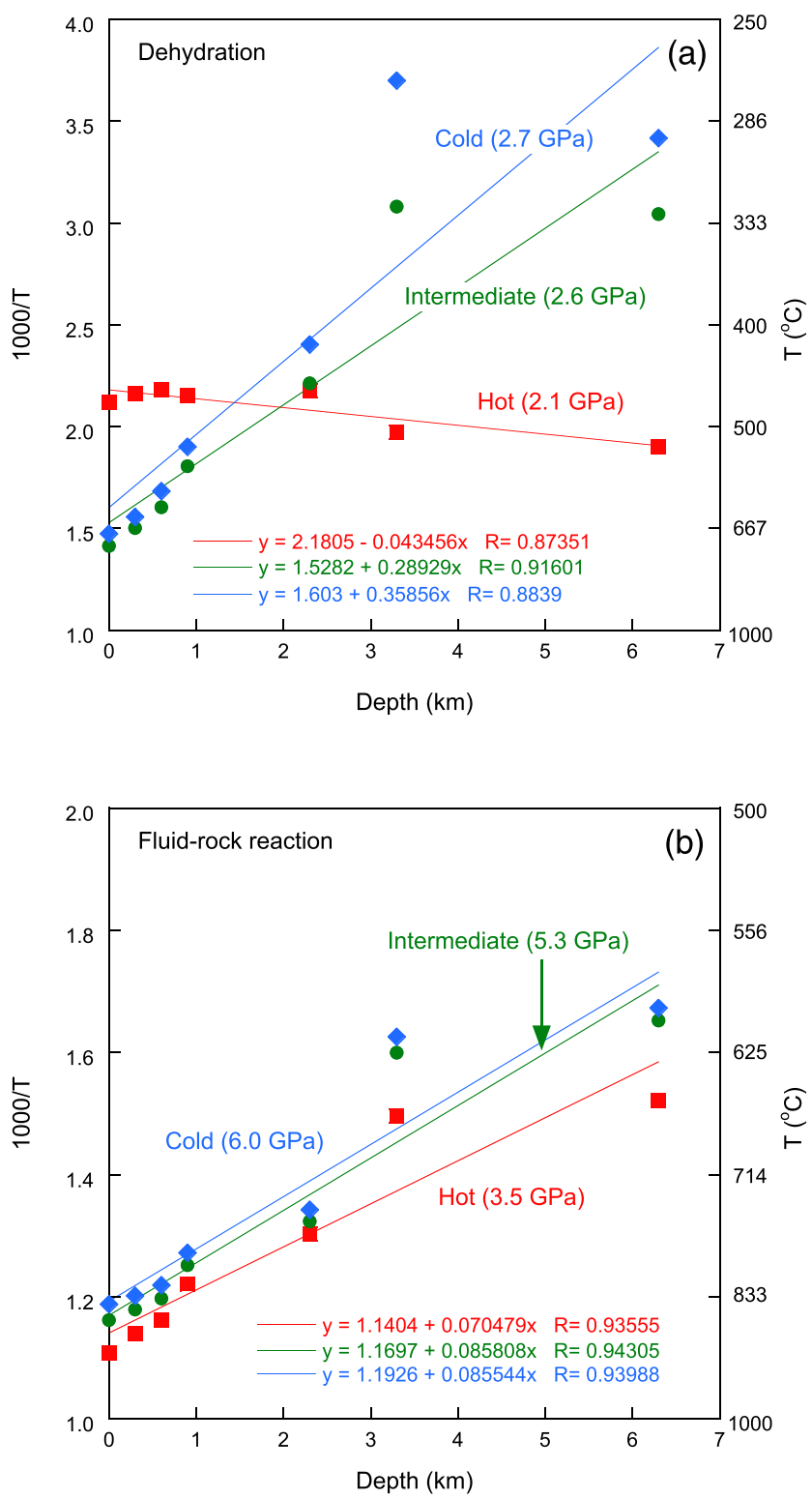

Figure A2. Thermal gradients in subducting oceanic crust during (a) dehydration reactions and (b) fluid-rock reactions. The thermal model is from Kimura et al. (2014), based on Syracuse et al. (2010) and van Keken et al. (2011). Depths of plotted points in the oceanic crust correspond to the top surfaces of layers in the modeled slab, consisting of sediment $(0 \mathrm{~km})$, upper volcanics $(0.3 \mathrm{~km})$, lower volcanics $(0.6 \mathrm{~km})$, dikes $(0.9 \mathrm{~km})$, upper gabbro $(2.3 \mathrm{~km})$, lower gabbro $(3.3 \mathrm{~km})$, and peridotite $(6.3 \mathrm{~km})$.

$$
C_{L}=\int_{x 1}^{x 0}\left(C_{\mathrm{S}} /\left(a e^{b(k x+w)}(1-F)+F\right)\right) d x 1 / O C,
$$

where $x 0$ and $x 1$ are the depths at the surface and bottom of the crust, respectively, and $O C$ is the thickness of the oceanic crust. Rewriting equation (5) as

$$
x=1 / k(t-w)
$$

we obtain the following equation:

$$
d x / d t=1 / k
$$

Thus, equation (7) can be rewritten as 
$C_{L}=\int_{t 1}^{t 0}\left(C_{\mathrm{S}} /\left(a e^{b t}(1-F)+F\right)\right)(1 / k) d t 1 / O C$,

where $t 0$ and $t 1$ are the inverse of temperature at the surface and bottom of the oceanic crust, respectively. Therefore, the fluid composition can be determined from

$$
C_{L}=\left[\frac{C s t}{F}-\frac{C s}{F b} \ln \left\{(1-F) a e^{b t}+F\right\}\right]_{t 1}^{t 0} \frac{1}{O C} .
$$

We can estimate the chemical composition of fluid that is in equilibrium with oceanic crust, the temperature of which is correlated with depth. The chemical composition of residual oceanic crust can then be calculated using the mass balance between $C_{\mathrm{L}}$ and $C_{\mathrm{S}}$.

Note that equation (11) calculates the bulk composition of oceanic crust that has experienced fluid-rock reaction. As the chemical fractionation caused by fluid-rock reaction depends on temperature, crustal layers at different depths should have different chemical and isotopic compositions due to temperature-sensitive solubilities of elements. Hence, isotopic variation, particularly in $\mathrm{Pb}$ isotopes, should exist within oceanic crust. Because this effect could potentially contribute to the isotopic heterogeneity of the mantle, we assessed

Table A1

Isotopic Compositions of Top and Bottom $1 \mathrm{~km}$ of Recycled Oceanic Crust

\begin{tabular}{|c|c|c|c|c|c|c|}
\hline \multirow{3}{*}{$\begin{array}{l}\text { Oceanic } \\
\text { crust } \\
\text { composition }\end{array}$} & \multicolumn{6}{|c|}{ Composition after fluid-rock reaction } \\
\hline & \multicolumn{2}{|c|}{ Hot subduction zone (South Chile) } & \multicolumn{2}{|c|}{ Cold subduction zone (South Marianas) } & \multicolumn{2}{|c|}{ Moderate subduction zone (Western Aleutian) } \\
\hline & Top $1 \mathrm{~km}$ & Bottom $1 \mathrm{~km}$ & Top $1 \mathrm{~km}$ & Bottom $1 \mathrm{~km}$ & Top $1 \mathrm{~km}$ & Bottom $1 \mathrm{~km}$ \\
\hline \multicolumn{7}{|l|}{$0.5-\mathrm{Ga}$ crust } \\
\hline${ }^{87} \mathrm{Sr} /{ }^{86} \mathrm{Sr}$ & 0.702710 & 0.702673 & 0.702670 & 0.702634 & 0.702683 & 0.702636 \\
\hline${ }^{143} \mathrm{Nd} /{ }^{144} \mathrm{Nd}$ & 0.513061 & 0.513045 & 0.513074 & 0.513046 & 0.513115 & 0.513048 \\
\hline${ }^{176} \mathrm{Hf} /{ }^{177} \mathrm{Hf}$ & 0.283145 & 0.283142 & 0.283143 & 0.283142 & 0.283146 & 0.283142 \\
\hline${ }^{206} \mathrm{~Pb} /{ }^{204} \mathrm{~Pb}$ & 19.394 & 18.179 & 18.918 & 18.238 & 19.436 & 18.451 \\
\hline${ }^{207} \mathrm{~Pb} /{ }^{204} \mathrm{~Pb}$ & 15.532 & 15.463 & 15.505 & 15.466 & 15.534 & 15.478 \\
\hline${ }^{208} \mathrm{~Pb} /{ }^{204} \mathrm{~Pb}$ & 39.510 & 38.135 & 38.639 & 38.193 & 38.754 & 38.403 \\
\hline \multicolumn{7}{|l|}{$1.0 \mathrm{Ga}$ crust } \\
\hline${ }^{87} \mathrm{Sr} /{ }^{86} \mathrm{Sr}$ & 0.702721 & 0.702646 & 0.702639 & 0.702567 & 0.702667 & 0.702571 \\
\hline${ }^{143} \mathrm{Nd} /{ }^{144} \mathrm{Nd}$ & 0.512921 & 0.512890 & 0.512947 & 0.512891 & 0.513029 & 0.512896 \\
\hline${ }^{176} \mathrm{Hf} /{ }^{177} \mathrm{Hf}$ & 0.282939 & 0.282932 & 0.282934 & 0.282932 & 0.282940 & 0.282932 \\
\hline${ }^{206} \mathrm{~Pb} /{ }^{204} \mathrm{~Pb}$ & 21.474 & 18.700 & 20.338 & 18.828 & 21.510 & 19.299 \\
\hline${ }^{207} \mathrm{~Pb} /{ }^{204} \mathrm{~Pb}$ & 15.708 & 15.507 & 15.626 & 15.516 & 15.711 & 15.551 \\
\hline${ }^{208} \mathrm{~Pb} /{ }^{204} \mathrm{~Pb}$ & 41.587 & 38.537 & 39.642 & 38.659 & 39.924 & 39.113 \\
\hline \multicolumn{7}{|l|}{$1.5-\mathrm{Ga}$ crust } \\
\hline${ }^{87} \mathrm{Sr} /{ }^{86} \mathrm{Sr}$ & 0.702731 & 0.702619 & 0.702608 & 0.702500 & 0.702650 & 0.702505 \\
\hline${ }^{143} \mathrm{Nd} /{ }^{144} \mathrm{Nd}$ & 0.512781 & 0.512734 & 0.512820 & 0.512736 & 0.512943 & 0.512743 \\
\hline${ }^{176} \mathrm{Hf} /{ }^{177} \mathrm{Hf}$ & 0.282730 & 0.282720 & 0.282723 & 0.282719 & 0.282732 & 0.282720 \\
\hline${ }^{206} \mathrm{~Pb} /{ }^{204} \mathrm{~Pb}$ & 24.134 & 19.304 & 22.058 & 19.514 & 24.080 & 20.301 \\
\hline${ }^{207} \mathrm{~Pb} /{ }^{204} \mathrm{~Pb}$ & 16.036 & 15.584 & 15.842 & 15.604 & 16.031 & 15.678 \\
\hline${ }^{208} \mathrm{~Pb} /{ }^{204} \mathrm{~Pb}$ & 44.144 & 38.989 & 40.829 & 39.187 & 41.360 & 39.925 \\
\hline \multicolumn{7}{|l|}{ 2.0-Ga crust } \\
\hline${ }^{87} \mathrm{Sr} /{ }^{86} \mathrm{Sr}$ & 0.702742 & 0.702592 & 0.702578 & 0.702432 & 0.702633 & 0.702439 \\
\hline${ }^{143} \mathrm{Nd} /{ }^{144} \mathrm{Nd}$ & 0.512640 & 0.512577 & 0.512693 & 0.512580 & 0.512857 & 0.512590 \\
\hline${ }^{176} \mathrm{Hf} /{ }^{177} \mathrm{Hf}$ & 0.282519 & 0.282506 & 0.282510 & 0.282505 & 0.282523 & 0.282505 \\
\hline${ }^{206} \mathrm{~Pb} /{ }^{204} \mathrm{~Pb}$ & 27.657 & 20.011 & 24.188 & 20.323 & 27.364 & 21.504 \\
\hline${ }^{207} \mathrm{~Pb} /{ }^{204} \mathrm{~Pb}$ & 16.658 & 15.718 & 16.231 & 15.756 & 16.622 & 15.901 \\
\hline${ }^{208} \mathrm{~Pb} /{ }^{204} \mathrm{~Pb}$ & 47.419 & 39.506 & 42.274 & 39.792 & 43.187 & 40.873 \\
\hline
\end{tabular}


it quantitatively by calculating isotopic compositions of the uppermost and lowermost $1 \mathrm{~km}$ of crust originally of MORB composition after fluid-rock reactions (Table A1).

\section{Appendix B: Crust Composition From Slow-Spreading Ridges B.}

We estimated the average oceanic crust composition produced at slow-spreading ridges (10-40 mm/year) from

$$
C_{\mathrm{ave}}=\frac{\sum\left(C_{\mathrm{seg}} \times V_{\mathrm{sp}} \times L_{\mathrm{seg}}\right)}{\sum\left(V_{\mathrm{sp}} \times L_{\mathrm{seg}}\right)},
$$

where $C_{\text {ave }}$ is the average concentration of an element in MORB produced at slow-spreading ridges, $C_{\text {seg }}$ is the average concentration of an element in MORB from an individual ridge segment with a slow spreading rate (10-40 $\mathrm{mm} /$ year), $V_{\mathrm{sp}}$ is the spreading rate of the segment (i.e., $10-40 \mathrm{~mm} /$ year), and $L_{\mathrm{seg}}$ is the length of the segment. The resulting MORB compositions are listed in Table 1.

\section{Acknowledgments}

We thank T. Matsumoto, H. Shinohara, O. Ishizuka, Y. Harigane, H. Saomoto, and H. Nakamura for the valuable discussions. We also thank V. Salters, A Stracke, J. Rudge, and an anonymous reviewer for providing many critical and constructive comments. We are grateful to J. Blichert-Toft for the editorial handling and comments. This study was supported by a Grant-in-Aid for Scientific Research on Innovative Areas, KAKENHI grant JP15H05830, from the Japan Society for the Promotion of Science (JSPS). Chemical and isotopic compositions of oceanic crust used in this study are included in Table 1. Partition coefficients used in calculations are presented in Table 2 . Amount of elements added to oceanic crust during seawater alteration are shown in Table S1-1, which were estimated data presented in Bach et al. (2001, 2003), Emmermann and Puchelt (1980), Hart and Staudigel (1982, 1989), Kelley et al. (2003), and Staudigel et al. (1981, 1989, 1995, 1996)

\section{References}

Adam, J., Locmelis, M., Afonso, J. C., Rushmer, T., \& Fiorentini, M. L. (2014). The capacity of hydrous fluids to transport and fractionate incompatible elements and metals within the Earth's mantle. Geochemistry, Geophysics, Geosystems, 15, 2241-2253. https://doi.org/ $10.1002 / 2013$ GC005199

Ague, J. J., \& Nicolescu, S. (2014). Carbon dioxide released from subduction zones by fluid-mediated reactions. Nature Geoscience, 7, 355-360. Allègre, C. J., \& Turcotte, D. L. (1986). Implications of a two-component marble-cake mantle. Nature, 323, $123-127$.

Alt, J. C., Laverne, C., Vanko, D. A., Tartarotti, P., Teagle, D. A. H., Bach, W., et al. (1996). Hydrothermal alteration of a section of upper oceanic crust in the eastern equatorial Pacific: A synthesis of results from Site 504 (DSDP Legs 69, 70, and 83, and ODP Legs 111, 137, 140, and 148). In Proc. Ocean Drill. Program Sci. Results (Vol. 148, pp. 417-433). College Station, TX: Ocean Drilling Program.

Alt, J. C., \& Teagle, D. A. H. (2003). Hydrothermal alteration of upper oceanic crust formed at a fast-spreading ridge: Mineral, chemical, and isotopic evidence from ODP Site 801. Chemical Geology, 201(3-4), 191-211. https://doi.org/10.1016/S0009-2541(03)00201-8

Andreani, M., Mével, C., Boullier, A.-M., \& Escartin, J. (2007). Dynamic control on serpentine crystallization in veins: constraints on hydration processes in oceanic peridotites. Geochemistry, Geophysics, Geosystems, 8, Q02012. https://doi.org/10.1029/2006GC001373

Ayers, J. (1998). Trace element modeling of aqueous fluid-peridotite interaction in the mantle wedge of subduction zones. Contributions to Mineralogy and Petrology, 132, 390-404.

Bach, W., Alt, J. C., Niu, Y., Humphris, S. E., Erzinger, J., \& Dick, H. J. B. (2001). The geochemical consequences of late-stage low-grade alteration of lower ocean crust at the SW Indian Ridge: Results from ODP Hole 735B (Leg 176). Geochimica et Cosmochimica Acta, 65, 3267-3287.

Bach, W., Peucker-Ehrenbrink, B., Hart, S. R., \& Blusztjan, J. S. (2003). Geochemistry of hydrothermally altered oceanic crust: DSDP/ODP Hole 504B-Implications for seawater-crust exchange budgets and $\mathrm{Sr}$ - and $\mathrm{Pb}$-isotopic evolution of the mantle. Geochemistry, Geophysics, Geosystems, 4(3), 8904. https://doi.org/10.1029/2002GC000419

Billen, M., \& Gurnis, M. (2005). Constraints on subducting plate strength within the Kermadec trench. Journal of Geophysical Research, 110, B05407. https://doi.org/10.1029/2004JB003308

Bose, K., \& Ganguly, J. (1995). Experimental and theoretical studies of the stabilities of talc, antigorite and phase A at high pressures with applications to subduction processes. Earth and Planetary Science Letters, 136, 109-121.

Bouvier, A., \& Boyet, M. (2016). Primitive solar system materials and Earth share a common initial ${ }^{142}$ Nd abundance. Nature, 537, 399-402. https://doi.org/10.1038/nature19351

Boyet, M., \& Carlson, R. W. (2005). ${ }^{142} \mathrm{Nd}$ evidence for early (>4.53 Ga) global differentiation of the silicate Earth. Science, 309, 576-581.

Boyet, M., \& Carlson, R. W. (2006). A new geochemical model for the Earth's mantle inferred from ${ }^{146} \mathrm{Sm}^{-142} \mathrm{Nd}$ systematics. Earth and Planetary Science Letters, 250, 254-268.

Brenan, J. M., Shaw, H. F., Ryerson, F. J., \& Phinney, D. L. (1995). Mineral-aqueous fluid partitioning of trace elements at $900{ }^{\circ} \mathrm{C}$ and 2.0 GPa: Constraints on the trace element chemistry of mantle and deep crustal fluids. Geochimica et Cosmochimica Acta, 59, 3331-3350.

Brovarone, A. V., Chu, X., Martin, L., Ague, J. J., Monie, P., Groppo, C., et al. (2018). Intra-slab COH fluid fluxes evidenced by fluidmediated decarbonation of lawsonite eclogite-facies altered oceanic metabasalts. Lithos, 304-307, 211-229.

Burkhardt, C., Borg, L. E., Brennecka, G. A., Shollenberger, Q. R., Dauphas, N., \& Kleine, T. (2016). A nucleosynthetic origin for the Earth's anomalous ${ }^{142} \mathrm{Nd}$ composition. Nature, 537, 394-398. https://doi.org/10.1038/nature18956

Cai, C., Wiens, D. A., Weisen, S., \& Eimer, M. (2018). Water input into the Mariana subduction zone estimated from ocean-bottom seismic data. Nature, 563, 389-392.

Carbotte, S. M., \& Scheirer, D. S. (2004). Variability of ocean crustal structure created along the global mid-ocean ridge. In E. E. Davis, \& H. Elderfield (Eds.), Hydrogeology of Oceanic Lithosphere (pp. 128-150). New York: Cambridge Univ. Press.

Castillo, P. R. (2015). The recycling of marine carbonates and sources of HIMU and FOZO ocean island basalts. Lithos, 216-217, 254-263. https://doi.org/10.1016/j.lithos.2014.12.005

Chase, C. G. (1981). Oceanic island lead: two-stage histories and mantle evolution. Earth and Planetary Science Letters, 52, $277-284$.

Chauvel, C., Hofmann, W. W., \& Vidal, P. (1992). HIMU-EM: The French Polynesian connection. Earth and Planetary Science Letters, 110, 99-119.

Chauvel, C., McDonough, W., Guille, G., Maury, R., \& Duncan, R. (1997). Contrasting old and young volcanism in Rurutu Island, Austral chain. Chemical Geology, 139, 125-143.

Christensen, U. R., \& Hofmann, A. W. (1994). Segregation of subducted oceanic crust in the convecting mantle. Journal of Geophysical Research, 99(B10), 19,867-19,884. https://doi.org/10.1029/93JB03403 
Connolly, J. A. D. (2005). Computation of phase equilibria by linear programming: A tool for geodynamic modeling and its application to subduction zone decarbonation. Earth and Planetary Science Letters, 236, 524-541.

Contreras-Reyes, E., Grevemeyer, I., Flueh, E. R., \& Reichert, C. (2008). Upper lithospheric structure of the subduction zone offshore of southern Arauco Peninsula, Chile, at $38^{\circ}$ S. Journal of Geophysical Research, 113, B07303. https://doi.org/10.1029/2007JB005569

Contreras-Reyes, E., Grevemeyer, I., Flueh, E. R., Scherwath, M., \& Bialas, J. (2008). Effect of trench-outer rise bending-related faulting on seismic Poisson's ratio and mantle anisotropy: A case study offshore of southern central Chile. Geophysical Journal International, 173, 142-156. https://doi.org/10.1111/j.1365-246X.2008.03716.x

Contreras-Reyes, E., Grevemeyer, I., Watts, A. B., Fluch, E. R., Peirce, C., Moeller, S., \& Papenburg, C. (2011). Deep seismic structure of the Tonga subduction zone: Implications for mantle hydration, tectonic erosion, and arc magmatism. Journal of Geophysical Research, 116, B10103. https://doi.org/10.1029/2011JB008434

Dasgupta, R., \& Hirschmann, M. M. (2010). The deep carbon cycle and melting in Earth's interior. Earth and Planetary Science Letters, 298 , $1-13$

DePaolo, D. J., \& Wasserburg, G. J. (1976a). Inferences about magma sources and mantle structure from variations of ${ }^{143} \mathrm{Nd} /{ }^{144} \mathrm{Nd}$. Geophysical Research Letters, 3, 743-746.

DePaolo, D. J., \& Wasserburg, G. J. (1976b). Nd isotopic variations and petrogenetic models. Geophysical Research Letters, 3, $249-252$.

Deschamps, F., Godard, M., Guillot, S., \& Hattori, K. (2013). Geochemistry of subduction zone serpentinites: A review. Lithos, 178, 96-127.

Elliott, T., Zindler, A., \& Bourdon, B. (1999). Exploring the kappa conundrum: The role of recycling in the lead isotope evolution of the mantle. Earth and Planetary Science Letters, 169, 129-145.

Emmermann, R., \& Puchelt, H. (1980). Major and trace element chemistry of basalts from holes 417D and 418A, deep sea drilling project legs 51-5. In T. Donnelly, J. Francheteau, W. Bryan, P. Robinson, M. Flower, \& M. Salisbury (Eds.), Deep Sea Drilling Project Initial Reports (Vol. 51, 52, \& 53, pp. 987-1000). Washington, DC: U.S. Government Printing Office.

Escartin, J., Hirth, G., \& Evans, B. (1997). Effects of serpentinization on the lithospheric strength and the style of normal faulting at slowspreading ridges. Earth and Planetary Science Letters, 151, 181-189.

Faccenda, M. (2014). Water in the slab: A trilogy. Tectonophysics, 614, 1-30. https://doi.org/10.1016/j.tecto.2013.12.020

Faccenda, M., Gerya, T. V., \& Burlini, L. (2009). Deep slab hydration induced by bending-related variations in tectonic pressure. Nature Geoscience, 2(11), 790-793. https://doi.org/10.1038/ngeo656

Facq, S., Daniel, I., Montagnac, G., Cardon, H., \& Sverjensky, D. A. (2016). Carbon speciation in saline solutions in equilibrium with aragonite at high pressure. Chemical Geology, 431, 44-53.

Facq, S. B., Daniel, I., Montagnac, G., Cardon, H., \& Sverjensky, D. A. (2014). In situ Raman study and thermodynamic model of aqueous carbonate speciation in equilibrium with aragonite under subduction zone conditions. Geochimica et Cosmochimica Acta, 132, 375-390.

Farley, K. A., Natland, J. H., \& Craig, H. (1992). Binary mixing of enriched and undegassed (primitive-questionable) mantle components $(\mathrm{He}, \mathrm{Sr}, \mathrm{Nd}, \mathrm{Pb})$ in Samoan lavas. Earth and Planetary Science Letters, 111, 183-199.

Fisher, A. T., Davis, E. E., Hutnak, M., Spiess, V., Zühlsdorff, L., Cherkaoui, A., et al. (2003). Hydrothermal recharge and discharge across $50 \mathrm{~km}$ guided by seamounts on a young ridge flank. Nature, 421, 618-621.

Frezzotti, M. L., Selverstone, J., Sharp, Z. D., \& Compagnoni, R. (2011). Carbonate dissolution during subduction revealed by diamondbearing rocks from the Alps. Nature Geoscience, 4, 703-706. https://doi.org/10.1038/ngeo1246

Fryer, P., Wheat, C. G., \& Mottl, M. L. (1999). Mariana blueschist mud volcanism: Implications for conditions within the subduction zone. Geology, 27, 103-106.

Fujie, G., Kodaira, S., Kaiho, Y., Yamamoto, Y., Takahashi, T., Miura, S., \& Yamada, T. (2018). Controlling factor of incoming plate hydration at the north-western Pacific margin. Nature Communications, 9, 3844.

Gale, A., Dalton, C. A., Langmuir, C. H., Su, Y. J., \& Schilling, J. G. (2013). The mean composition of ocean ridge basalts. Geochemistry, Geophysics, Geosystems, 14, 489-518. https://doi.org/10.1029/2012GC004334

Garth, T., \& Rietbrock, A. (2014). Order of magnitude increase in subducted $\mathrm{H}_{2} \mathrm{O}$ due to hydrated normal faults within the Wadati-Benioff zone. Geology, 42(3), 207-210. https://doi.org/10.1130/G34730.1

Garth, T., \& Rietbrock, A. (2017). Constraining the hydration of the subducting Nazca plate beneath Northern Chile using subduction zone guided waves. Earth and Planetary Science Letters, 474, 237-247.

Gast, P. W. (1968). Trace element fractionation and the origin of tholeiitic and alkaline magma types. Geochimica et Cosmochimica Acta, 32, 1067-1086.

Gorman, P. J., Kerrick, D. M., \& Connolly, J. A. D. (2006). Modeling open system metamorphic decarbonation of subducting slabs. Geochemistry, Geophysics, Geosystems, 7, Q04007. https://doi.org/10.1029/2005GC001125

Green, T. H., \& Adam, J. (2003). Experimentally determined trace element characteristics of aqueous fluid from partially dehydrated mafic oceanic crust at $3.0 \mathrm{GPa}, 650-700^{\circ} \mathrm{C}$. European Journal of Mineralogy, 15, 815-830. https://doi.org/10.1127/0935-1221/2003/0015-0815

Hacker, B. R. (2008). $\mathrm{H}_{2} \mathrm{O}$ subduction beyond arcs. Geochemistry, Geophysics, Geosystems, 9, Q03001. https://doi.org/10.1029/ 2007GC001707

Hacker, B. R., Abers, G. A., \& Peacock, S. M. (2003). Subduction factory 1 . Theoretical mineralogy, densities, seismic wave speeds, and $\mathrm{H}_{2} \mathrm{O}$ contents. Journal of Geophysical Research, 108(B1), 2029. https://doi.org/10.1029/2001JB001127

Halldórsson, S. A., Hilton, D. R., Barry, P. H., Füri, E., \& Grönvold, K. (2016). Recycling of crustal material by the Iceland mantle plume: new evidence from nitrogen elemental and isotope systematics of subglacial basalts. Geochimica et Cosmochimica Acta, 176, $206-226$.

Hammouda, T. (2003). High-pressure melting of carbonated eclogite and experimental constraints on carbon recycling and storage in the mantle. Earth and Planetary Science Letters, 214, 357-368.

Hanan, B. B., \& Graham, D. W. (1996). Lead and helium isotope evidence from oceanic basalts for a common deep source of mantle plumes. Science, 271, 991-995.

Hanyu, T., Tatsumi, Y., \& Kimura, J.-I. (2011). Constraints on the origin of the HIMU reservoir from He-Ne-Ar isotope systematics. Earth and Planetary Science Letters, 307, 377-386.

Hart, S., \& Staudigel, H. (1982). The control of alkalies and uranium in seawater by ocean crust alteration. Earth and Planetary Science Letters, 58, 202-212.

Hart, S. R., Blusztajn, J., Dick, H. J. B., Meyer, P. S., \& Muehlenbachs, K. (1999). The fingerprint of seawater circulation in a 500-meter section of ocean crust gabbros. Geochimica et Cosmochimica Acta, 63, 4059-4080.

Hart, S. R., Hauri, E. H., Oschmann, L. A., \& Whitehead, J. A. (1992). Mantle plumes and entrainment: Isotopic evidence. Science, 256, 517-520.

Hart, S. R., \& Staudigel, H. (1989). Isotopic characterization and identification of recycled components. In S. R. Hart, \& L. Glen (Eds.), Crust/Mantle Recycling at Convergence Zones, NATO ASI Series. Series C, Mathematical and Physical Sciences, (Vol. 258, pp. 15-28). Dordrecht: D. Reidel Publishing Company. 
Hauri, E. H., \& Hart, S. R. (1993). Re-Os isotope systematics of HIMU and EMII oceanic island basalts from the South-Pacific Ocean. Earth and Planetary Science Letters, 114, 353-371.

Hermann, J., Spandler, C., Hack, A., \& Korsakov, A. V. (2006). Aqueous fluids and hydrous melts in high-pressure and ultra-high pressure rocks: Implications for element transfer in subduction zones. Lithos, 92(3), 399-417.

Hofmann, A. W. (1997). Mantle geochemistry: The message from oceanic volcanism. Nature, 385, 219-229.

Hofmann, A. W., \& White, W. M. (1982). Mantle plumes from ancient oceanic crust. Earth and Planetary Science Letters, 57, 421-436. https://doi.org/10.1016/0012821X(82)90161-3

Ildefonse, B., Blackman, D. K., John, B. E., Ohara, Y., Miller, D. J., \& MacLeod, C. J. (2007). Oceanic core complexes and crustal accretion at slow-spreading ridges. Geology, 35, 623-626.

Iwamori, H. (1998). Transportation of $\mathrm{H}_{2} \mathrm{O}$ and melting in subduction zones. Earth and Planetary Science Letters, 160, 65-80.

Iwamori, H. (2000). Deep subduction of $\mathrm{H}_{2} \mathrm{O}$ and deflection of volcanic chain towards backarc near triple junction due to lower temperature. Earth and Planetary Science Letters, 181, 41-46. https://doi.org/10.1016/S0012-821X(00)00180-1

Iwamori, H. (2004). Phase relations of peridotites under $\mathrm{H}_{2} \mathrm{O}$-saturated conditions and ability of subducting plates for transportation of $\mathrm{H}_{2} \mathrm{O}$. Earth and Planetary Science Letters, 227, 57-71.

Iwamori, H. (2007). Transportation of $\mathrm{H}_{2} \mathrm{O}$ beneath the Japan arcs and its implications for global water circulation. Chemical Geology, 239, 182-198.

Iwamori, H., \& Albarède, F. (2008). Decoupled isotopic record of ridge and subduction zone processes in oceanic basalts by independent component analysis. Geochemistry, Geophysics, Geosystems, 9, Q04033. https://doi.org/10.1029/2007GC001753

Iwamori, H., Albarède, F., \& Nakamura, H. (2010). Global structure of mantle isotopic heterogeneity and its implications for mantle differentiation and convection. Earth and Planetary Science Letters, 299, 339-351. https://doi.org/10.1016/j.epsl.2010.09.014

Jackson, M. G., Becker, T. W., \& Konter, J. G. (2018). Geochemistry and Distribution of Recycled Domains in the Mantle Inferred From Nd and $\mathrm{Pb}$ Isotopes in Oceanic Hot Spots: Implications for Storage in the Large Low Shear Wave Velocity Provinces. Geochemistry, Geophysics, Geosystems, 19, 3496-3519. https://doi.org/10.1029/2018GC007552

Jackson, M. G., Carlson, R. W., Kurz, M. D., Kempton, P. D., Francis, D., \& Blusztajn, J. (2010). Evidence for the survival of the oldest terrestrial mantle reservoir. Nature, 466(7308), 853-856. https://doi.org/10.1038/nature09287

Jarrard, R. D. (2003). Subduction fluxes of water, carbon dioxide, chlorine, and potassium. Geochemistry, Geophysics, Geosystems, 4(5), 8905. https://doi.org/10.1029/2002GC000392

Kawamoto, T., Yoshikawa, M., Kumagai, Y., Mirabueno, M. H. T., Okuno, M., \& Kobayashi, T. (2013). Mantle wedge infiltrated with saline fluids from dehydration and decarbonation of subducting slab. Proceedings of the National Academy of Sciences of the United States of America, 110, 9663-9668. https://doi.org/10.1073/pnas.1302040110

Kelemen, P. B., \& Manning, C. E. (2015). Reevaluating carbon fluxes in subduction zones, what goes down, mostly comes up. Proceedings of the National Academy of Sciences of the United States of America, 112, E3997-E-4006. https://doi.org/10.1073/pnas.1507889112 (201507889)

Kelemen, P. B., Rilling, J. L., Parmentier, E. M., Mehl, L., \& Hacker, B. R. (2003). Thermal structure due to solid-state flow in the mantle wedge beneath arcs. In J. Eiler (Ed.), Inside the Subduction Factory, Geophysical Monograph Series (Vol. 138, pp. 293-311). Washington, DC: American Geophysical Union.

Kelley, K. A., Plank, T., Farr, L., Ludden, J., \& Staudigel, H. (2005). Subduction cycling of U, Th, and Pb. Earth and Planetary Science Letters, 234, 369-383.

Kelley, K. A., Plank, T., Ludden, J., \& Staudigel, H. (2003). Composition of altered oceanic crust at ODP Sites 801 and 1149. Geochemistry, Geophysics, Geosystems, 4(6), 8910. https://doi.org/10.1029/2002GC000435

Kellogg, J. B., Jacobsen, S. B., \& O'Connell, R. J. (2007). Modeling lead isotopic heterogeneity in mid-ocean ridge basalts. Earth and Planetary Science Letters, 262, 328-342.

Kessel, R., Schmidt, M. W., Ulmer, P., \& Pettke, T. (2005). Trace element signature of subduction-zone fluids, melts and supercritical liquids at $120-180 \mathrm{~km}$ depth. Nature, 437, 724-727.

Kessel, R., Ulmer, P., Pettke, T., Schmidt, M. W., \& Thompson, A. B. (2005). The water-basalt system at 4 to 6 GPa: Phase relations and second critical endpoint in a K-free eclogite at 700 to $1400{ }^{\circ} \mathrm{C}$. Earth and Planetary Science Letters, 237, 873-892. https://doi.org/10.1016/ j.epsl.2005.06.018

Kimura, J.-I., Gill, J. B., Skora, S., van Keken, P. E., \& Kawabata, H. (2016). Origin of geochemical mantle components: Role of subduction filter. Geochemistry, Geophysics, Geosystems, 17, 3289-3325. https://doi.org/10.1002/2016GC006362

Kimura, J.-I., Gill, J. B., van Keken, P. E., \& Kawabata, H. (2017). Origin of geochemical mantle components: Role of spreading ridges and thermal evolution of mantle. Geochemistry, Geophysics, Geosystems, 18, 697-734. https://doi.org/10.1002/2016GC006696

Kimura, J.-I., Gill, J. B., Kunikiyo, T., Osaka, I., Shimoshioiri, Y., Katakuse, M., et al. (2014). Diverse magmatic effects of subducting a hot slab in SW Japan: Results from forward modeling. Geochemistry, Geophysics, Geosystems, 15(3), 691-739. https://doi.org/10.1002/ $2013 \mathrm{gc} 005132$

Kogiso, T., Tatsumi, Y., \& Nakano, S. (1997). Trace element transport during dehydration processes in the subducted oceanic crust: 1. experiments and implications for the origin of ocean island basalts. Earth and Planetary Science Letters, 148, 193-205.

Komabayashi, T., Hirose, K., Funakoshi, K.-i., \& Takafuji, N. (2005). Stability of phase A in antigorite (serpentine) composition determined by in situ X-ray pressure observations. Physics of the Earth and Planetary Interiors, 151, 276-289.

Komabayashi, T., \& Omori, S. (2006). Internally consistent thermodynamic data set for dense hydrous magnesium silicates up to 35 $\mathrm{GPa}, 1600{ }^{\circ} \mathrm{C}$ : Implications for water circulation in the Earth's deep mantle. Physics of the Earth and Planetary Interiors, 156, 89-107.

Komabayashi, T., Omori, S., \& Maruyama, S. (2005). Experimental and theoretical study of stability of dense hydrous magnesium silicates in the deep upper mantle. Physics of the Earth and Planetary Interiors, 153, 191-209.

Korenaga, J. (2007). Thermal cracking and the deep hydration of oceanic lithosphere: A key to the generation of plate tectonics? Journal of Geophysical Research, 112, B05408. https://doi.org/10.1029/2006JB004502

Korenaga, J. (2017). On the extent of mantle hydration caused by plate bending. Earth and Planetary Science Letters, 457, 1-9. https://doi. org/10.1016/j.epsl.2016.10.011

Manning, C. E. (2004). The chemistry of subduction zone fluids. Earth and Planetary Science Letters, 223, 1-16.

McKenzie, D., \& O'Nions, R. K. (1983). Mantle reservoirs and ocean island basalts. Nature, 301, 229-231.

Mével, C. (2003). Serpentinization of abyssal peridotites at mid-ocean ridges. Comptes Rendus Géoscience, 335, 825-852.

Mibe, K., Kanzaki, M., Kawamoto, T., Matsukage, K. N., Fei, Y., \& Ono, S. (2007). Second critical endpoint in the peridotite-H2O system. Journal of Geophysical Research, 112, B03201. https://doi.org/10.1029/2005JB004125 
Mibe, K., Kawamoto, T., Matsukage, K. N., Fei, Y., \& Ono, S. (2011). Slab melting versus slab dehydration in subduction-zone magmatism. Proceedings of the National Academy of Sciences of the United States of America, 108, 8177-8182. https://doi.org/10.1073/pnas.1010968108

Mutter, A., Holzheid, A., Klügel, A., Wilke, M., Berndt, J., \& Garbe-Schönberg, D. (2014). Element signatures of subduction-zone fluids. An experimental study of the element partitioning $\left(\mathrm{D}^{\text {fluid/rock }}\right)$ of natural partly altered igneous rocks from the ODP drilling site 1256 International Journal of Earth Sciences, 103, 1917-1927.

Mutter, C. Z., \& Mutter, J. C. (1993). Variations in thickness of Layer 3 dominated oceanic crustal structure. Earth and Planetary Science Letters, 117, 295-317.

Nakajima, J., Hasegawa, A., \& Kita, S. (2011). Seismic evidence for reactivation of a buried hydrated fault in the Pacific slab by the 2011 M9.0 Tohoku earthquake. Geophysical Research Letters, 38, L00G06. https://doi.org/10.1029/2011GL048432

Nakamura, Y., \& Kushiro, I. (1974). Composition of the gas phase in $\mathrm{Mg}_{2} \mathrm{SiO}_{4}-\mathrm{SiO}_{2}-\mathrm{H}_{2} \mathrm{O}$ at 15 kbar. In Year Book Carnegie Institute (Vol. 73, pp. 255-258). Washington, DC: Carnegie Institution of Washington.

Nedimović, M. R., Bohnenstiehl, D. R., Carbotte, S. M., Canales, J. P., \& Dziak, R. P. (2009). Faulting and hydration of the Juan de Fuca plate system. Earth and Planetary Science Letters, 284, 94-102. https://doi.org/10.1016/j.epsl.2009.04.013

Nishi, M., Irifune, T., Tsuchiya, J., Tange, Y., Nishihara, Y., Fujino, K., \& Higo, Y. (2014). Stability of hydrous silicate at high pressures and water transport to the deep lower mantle. Nature Geoscience, 7, 224-227.

Niu, Y. (2004). Bulk-rock major and trace element compositions of abyssal peridotites: Implications for mantle melting, melt extraction and post-melting processes beneath mid-ocean ridges. Journal of Petrology, 45, 2423-2458. https://doi.org/10.1093/petrology/egh068

Ohtani, E., Yuan, L., Ohira, I., Shatskiy, A., \& Litasov, K. (2018). Fate of water transported into the deep mantle by slab subduction. Journal of Asia Earth Sciences, 167, 2-10. https://doi.org/10.1016/j.jseaes.2018.04.024

Okamoto, K., \& Maruyama, S. (2004). The eclogite-gametite transformation in the MORB $+\mathrm{H}_{2} \mathrm{O}$ system. Physics of the Earth and Planetary Interiors, 146, 283-296.

Omori, S., Komabayashi, T., \& Maruyama, S. (2004). Dehydration and earthquakes in the subducting slab: empirical link in intermediate and deep seismic zones. Physics of the Earth and Planetary Interiors, 146, 297-311.

O'Nions, R. K., Hamilton, P. J., \& Evensen, N. M. (1977). Variations in ${ }^{143} \mathrm{Nd} /{ }^{144} \mathrm{Nd}$ and ${ }^{87} \mathrm{Sr} /{ }^{86} \mathrm{Sr}$ ratios in oceanic basalts. Earth and Planetary Science Letters, 34, 13-22.

Parai, R., \& Mukhopadhyay, S. (2012). How large is the subducted water flux? New constraints on mantle regassing rates. Earth and Planetary Science Letters, 317-318, 396-406. https://doi.org/10.1016/j.epsl.2011.11.024

Peacock, S. M. (2001). Are the lower planes of double seismic zones caused by serpentine dehydration in subducting oceanic mantle? Geology, 29, 299-302.

Peacock, S. M., \& Wang, K. (1999). Seismic consequence of warm versus cool subduction metamorphism: Examples from southwest and northeast Japan. Science, 286, 937-939. https://doi.org/10.1126/science.286.5441.937

Pertermann, M., \& Hirschmann, M. M. (2003). Partial melting experiments on a MORB-like pyroxenite between 2 and 3 GPa: Constraints on the presence of pyroxenite in basalt source regions from solidus location and melting rate. Journal of Geophysical Research, 108(B2), 2125. https://doi.org/10.1029/2000JB000118

Piccoli, F., Vitale Brovarone, A., \& Ague, J. J. (2018). Field and petrological study of metasomatism and high-pressure carbonation from lawsonite eclogite-facies terrains. Alpine Corsica. Lithos, 304-307, 16-37.

Piccoli, F., Vitale Brovarone, A., Beyssac, O., Martinez, I., Ague, J. J., \& Chaduteau, C. (2016). Carbonation by fluid-rock interactions at high-pressure conditions: Implications for carbon cycling in subduction zones. Earth and Planetary Science Letters, 445, 146-159. https:// doi.org/10.1016/j.epsl.2016.03.045

Plank, T., Cooper, L. B., \& Manning, C. E. (2009). Emerging geothermometers for estimating slab surface temperatures. Nature Geoscience, $2,611-615$.

Plank, T., Ludden, J. N., Escutia, C., Abrams, L. J., Alt, J. C., Armstrong, R. N., et al. (2000). Site 801. In T. Plank, J. N. Ludden, \& C. Escutia (Eds.), Proceedings of the Ocean Drilling Program, Initial Reports (Vol. 185, pp. 1-222). Texas: College Station: Ocean Drilling Program.

Poli, S., Franzolin, E., Fumagalli, P., \& Crottini, A. (2009). The transport of carbon and hydrogen in subducted oceanic crust: An experimental study to $5 \mathrm{GPa}$. Earth and Planetary Science Letters, 278, 350-360.

Poli, S., \& Schmidt, M. W. (1995). $\mathrm{H}_{2} \mathrm{O}$ transport and release in subduction zones: Experimental constraints on basaltic and andesitic systems. Journal of Geophysical Research, 100(B11), 22299-22314. https://doi.org/10.1029/95JB01570

Ranero, C. R., Phipps Morgan, J., McIntosh, K., \& Reichert, C. (2003). Bending-related faulting and mantle serpentinization at the Middle America trench. Nature, 425(6956), 367-373.

Ranero, C. R., Villasenor, A., Morgan, P. J., \& Weinrebe, W. (2005). Relationship between bend-faulting at trenches and intermediate-depth seismicity. Geochemistry, Geophysics, Geosystems, 6, Q12002. https://doi.org/10.1029/2005GC000997

Richard, P. N., Shimizu, N., \& Allègre, C. J. (1976). ${ }^{143} \mathrm{Nd} /{ }^{144} \mathrm{Nd}$, a natural tracer: An application to oceanic basalts. Earth and Planetary Science Letters, 31, 269-278.

Ridley, W. I., Perfit, M. R., Jonasson, I. R., \& Smith, M. F. (1994). Hydrothermal alteration in oceanic ridge volcanics: a detailed study at the Galápagos fossil hydrothermal field. Geochimica et Cosmochimica Acta, 58, 2477-2494.

Rizo, H., Walker, R. J., Carlson, R. W., Horan, M. F., Mukhopadhyay, S., Manthos, V., et al. (2016). Preservation of Earth-forming events in the tungsten isotopic composition of modern flood basalts. Science, 352(6287), 809-812. https://doi.org/10.1126/science.aad8563

Robinson, P. T., Flower, M. F. J., Schmincke, H. U., \& Ohnmacht, W. (1997). Low Temperature Alteration of Oceanic Basalts, DSDP Leg 37, Initial Rep DSDP (Vol. 37, pp. 775-793). Washington, US: Government Printing Office.

Rudge, J. F. (2006). Mantle pseudo-isochrons revisited. Earth and Planetary Science Letters, 249, 494-513. https://doi.org/10.1016/j. epsl.2006.06.046

Rudge, J. F., McKenzie, D., \& Haynes, P. H. (2005). A theoretical approach to understanding the isotopic heterogeneity of mid-ocean ridge basalt. Geochimica et Cosmochimica Acta, 69, 3873-3887.

Salters, V. J. M., Mallick, S., Hart, S. R., Langmuir, C. E., \& Stracke, A. (2011). Domains of depleted mantle: New evidence from hafnium and neodymium isotopes. Geochemistry, Geophysics, Geosystems, 12, Q08001. https://doi.org/10.1029/2011GC003617

Salters, V. J. M., \& White, W. M. (1998). Hf isotope constraints on mantle evolution. Chemical Geology, 145, 447-460.

Scambelluri, M., Fiebig, J., Malaspina, N., Müntener, O., \& Pettked, T. (2004). Serpentinite subduction: Implications for fluid processes and trace-element recycling. International Geology Review, 46, 595-613. https://doi.org/10.2747/0020-6814.46.7.595

Schmidt, M. W., \& Poli, S. (1998). Experimentally based water budgets for dehydrating slabs and consequences for arc magma generation. Earth and Planetary Science Letters, 163, 361-379.

Schmidt, M. W., Vielzeuf, D., \& Auzanneau, E. (2004). Melting and dissolution of subducting crust at high pressures: The key role or white micas. Earth and Planetary Science Letters, 228, 65-84. 
Shaw, H. R. (1970). Trace element fractionation during anatexis. Geochimica et Cosmochimica Acta, 34, $237-243$.

Shieh, S. R., Mao, H., Hemley, R. J., \& Ming, L. C. (1998). Decomposition of phase D in the lower mantle and the fate of dense hydrous silicates in subducting slabs. Earth and Planetary Science Letters, 159, 13-23. https://doi.org/10.1016/S0012-821X(98)00062-4

Shields, G., Carden, G., Veizer, J., Meidla, T., Rong, J.-Y., \& Li, R. (2003). Sr, C and O isotope geochemistry of Ordovician brachiopods: A major isotopic event around the Middle-Late Ordovician transition. Geochimica et Cosmochimica Acta, 67, $2005-2025$.

Shields, G., \& Veizer, J. (2002). Precambrian marine carbonate isotope database: Version 1.1. Geochemistry, Geophysics, Geosystems, 3(6), 1031. https://doi.org/10.1029/2001GC000266

Shimoda, G. (2009). Genetic link between EMI and EMII: an adakite connection. Lithos, 112, 591-602.

Spandler, C., \& Pirard, C. (2013). Element recycling from subducting slabs to crust: A review. Lithos, 170-171, 208-223. https://doi.org/ 10.1016/j.lithos.2013.02.016

Stakes, D. S., \& Franklin, J. M. (1994). Petrology of igneous rocks at middle valley, Juan de Fuca ridge. In M. J. Mottl, E. E. Davis, A. T. Fisher, \& J. F. Slack (Eds.), Proc. Ocean Drill. Program Sci. Results (Vol. 139, pp. 79-102). College Station, TX.

Staudigel, H. (2003). Hydrothermal alteration processes in the oceanic crust. In H. D. Holland, \& K. K. Turekian (Eds.), The Crust, Treatise on Geochemistry (Vol. 3, pp. 511-535). New York: Elsevier.

Staudigel, H., Davies, G. R., Hart, S. R., Marchant, K. M., \& Smith, B. M. (1995). Large scale isotopic Sr, Nd and O isotopic anatomy of altered oceanic crust: DSDP/ODP sites 417/418. Earth and Planetary Science Letters, 130, 169-185.

Staudigel, H., Hart, S. R., Schmincke, H. U., \& Smith, B. M. (1989). Cretaceous ocean crust at DSDP sites 417 and 418 : Carbon uptake from weathering versus loss by magmatic outgassing. Geochimica et Cosmochimica Acta, 53, 3091-3094.

Staudigel, H., Muehlenbachs, K., Richardson, S. H., \& Hart, S. R. (1981). Agents of low temperature ocean crust alteration. Contributions to Mineralogy and Petrology, 77, 150-157.

Staudigel, H., Plank, T., White, B., \& Schmincke, H. -U. (1996). Geochemical fluxes during seafloor alteration of the basaltic upper crust: DSDP Sites 417 and 418. In G. E. Bebout, et al. (Eds.), Subduction: Top to Bottom, Geophysical Monograph Series (Vol. 96, pp. 19-38). Washington, DC: American Geophysical Union.

Stracke, A. (2012). Earth's heterogeneous mantle: A product of convection-driven interaction between crust and mantle. Chemical Geology, 330-331, 274-299. https://doi.org/10.1016/j.chemgeo.2012.08.007

Stracke, A., Bizimis, M., \& Salters, V. J. M. (2003). Recycling oceanic crust: quantitative constraints. Geochemistry, Geophysics, Geosystems, 4(3), 8003. https://doi.org/10.1029/2001GC000223

Stracke, A., Hofmann, A. W., \& Hart, S. R. (2005). FOZO, HIMU, and the rest of the mantle zoo. Geochemistry, Geophysics, Geosystems, 6, Q05007. https://doi.org/10.1029/2004GC000824

Sun, S.-s., \& McDonough, W. F. (1989). Chemical and isotopic systematics of oceanic basalts: Implications for mantle composition and processes. Geological Society - Special Publications, 42, 313-345.

Syracuse, E. M., \& Abers, G. A. (2006). Global compilation of variations in slab depth beneath arc volcanoes and implications. Geochemistry, Geophysics, Geosystems, 7, Q05017. https://doi.org/10.1029/2005GC001045

Syracuse, E. M., van Keken, P. E., \& Abers, G. A. (2010). The global range of subduction zone thermal models. Physics of the Earth and Planetary Interiors, 183, 73-90.

Tatsumi, Y. (1989). Migration of fluid phases and genesis of basalt magmas in subduction zones. Journal of Geophysical Research, 94(B4), 4697-4707. https://doi.org/10.1029/JB094iB04p04697

Tatsumoto, M., Knight, R. J., \& Allegre, C. J. (1973). Time differences in the formation of meteorites as determined from the ratio of lead207 to lead-206. Science, 180, 1279-1283.

Ulmer, P., \& Trommsdorff, V. (1995). Serpentine stability to mantle depths and subduction-related magmatism. Science, 268, 858-861.

van Avendonk, H. J. A., Holbrook, W. S., Lizarralde, D., \& Denyer, P. (2011). Structure and serpentinization of the subducting Cocos plate offshore Nicaragua and Costa Rica. Geochemistry, Geophysics, Geosystems, 12, Q06009. https://doi.org/10.1029/2011GC003592

van Keken, P. E., Hacker, B. R., Syracuse, E. M., \& Abers, G. A. (2011). Subduction factory: 4. Depth-dependent flux of $\mathrm{H}_{2} \mathrm{O}$ from subducting slabs worldwide. Journal of Geophysical Research, 116, B01401. https://doi.org/10.1029/2010JB007922

van Keken, P. E., Wada, I., Abers, G. A., Hacker, B. R., \& Wang, K. (2018). Mafic high-pressure rocks are preferentially exhumed from warm subduction settings. Geochemistry, Geophysics, Geosystems, 19, 2934-2961. https://doi.org/10.1029/2018GC007624

Watts, A. B. (2001). Isostasy and Flexure of the Lithosphere. New York: Cambridge Univ. Press.

Weaver, B. L. (1991). The origin of ocean island basalt end-member compositions: trace element and isotopic constraints. Earth and Planetary Science Letters, 104, 381-397.

White, R. S., McKenzie, D., \& O'Nions, R. K. (1992). Ocean crustal thickness from seismic measurements and rare earth element inversions Journal of Geophysical Research, 97, 19,683-19,715.

White, W. M. (1985). Sources of oceanic basalts: Radiogenic isotopic evidence. Geology, 13, 115-118.

White, W. M. (2015). Isotopes, DUPAL, LLSVPs, and Anekantavada. Chemical Geology, 419, 10-28. https://doi.org/10.1016/j. chemgeo.2015.09.026

Willbold, M., \& Stracke, A. (2006). Trace element composition of mantle end-members: Implications for recycling of oceanic and upper and lower continental crust. Geochemistry, Geophysics, Geosystems, 7, Q04004. https://doi.org/10.1029/2005GC001005

Willbold, M., \& Stracke, A. (2010). Formation of enriched mantle components by recycling of upper and lower continental crust. Chemical Geology, 276, 188-197.

Workman, R. K., \& Hart, S. R. (2005). Major and trace element composition of the depleted MORB mantle (DMM). Earth and Planetary Science Letters, 231, 53-72. https://doi.org/10.1016/j.epsl.2004.12.005

Yogodzinski, G. M., Kelemen, P. B., Hoernle, K., Brown, S. T., Bindeman, I., Vervoort, J. D., et al. (2017). Sr and O isotopes in western Aleutian seafloor lavas: Implications for the source of fluids and trace element character of arc volcanic rocks. Earth and Planetary Science Letters, 475, 169-180.

Zindler, A., \& Hart, S. (1986). Chemical geodynamics. Annual Review of Earth and Planetary Sciences, 14, 493-571.

\section{References From the Supporting Information}

Arevalo, R., \& McDonough, W. F. (2010). Chemical variations and regional diversity observed in MORB. Chemical Geology, 271(1), 70-85. Becker, K., Sakai, H., Adamson, A. C., Alexandrovich, J., Alt, J. C., Anderson, R. N., et al. (1989). Drilling deep into young oceanic crust, Hole 504B, Costa Rica Rift. Reviews of Geophysics, 27(1), 79-102. https://doi.org/10.1029/RG027i001p00079 